\title{
Review \\ The Landscape of Nanovectors for Modulation in Cancer Immunotherapy
}

\author{
Simona-Ruxandra Volovat ${ }^{1,+}$, Corina Lupascu Ursulescu ${ }^{2,+}$, Liliana Gheorghe Moisii ${ }^{2,+}$, Constantin Volovat ${ }^{1,3, *}$, \\ Diana Boboc ${ }^{1,+}$, Dragos Scripcariu 4 , Florin Amurariti ${ }^{1,+}$, Cipriana Stefanescu ${ }^{5}$, Cati Raluca Stolniceanu ${ }^{5}$, \\ Maricel Agop ${ }^{6}$, Cristian Lungulescu ${ }^{7}$ and Cristian Constantin Volovat ${ }^{2}$
}

check for updates

Citation: Volovat, S.-R.; Ursulescu, C.L.; Moisii, L.G.; Volovat, C.; Boboc, D.; Scripcariu, D.; Amurariti, F.; Stefanescu, C.; Stolniceanu, C.R.; Agop, M.; et al. The Landscape of Nanovectors for Modulation in Cancer Immunotherapy. Pharmaceutics 2022, 14, 397. https:// doi.org/10.3390/pharmaceutics 14020397

Academic Editors: Bryan J. Mathis, Andrea Lancia and Alexander Zaboronok

Received: 30 November 2021

Accepted: 8 February 2022

Published: 11 February 2022

Publisher's Note: MDPI stays neutral with regard to jurisdictional claims in published maps and institutional affiliations.

Copyright: (C) 2022 by the authors. Licensee MDPI, Basel, Switzerland. This article is an open access article distributed under the terms and conditions of the Creative Commons Attribution (CC BY) license (https:// creativecommons.org/licenses/by/ $4.0 /)$.
1 Department of Medical Oncology-Radiotherapy, “Grigore T. Popa” University of Medicine and Pharmacy, 16 University Str., 700115 Iaşi, Romania; simonavolovat@gmail.com (S.-R.V.); dianaiboboc@gmail.com (D.B.); floryn_ciprian@yahoo.com (F.A.)

2 Department of Radiology, "Grigore T. Popa” University of Medicine and Pharmacy, 16 University Str., 700115 Iaşi, Romania; corina.ursulescu@gmail.com (C.L.U.); lgheorghe123@gmail.com (L.G.M.); cristian.volovat@yahoo.com (C.C.V.)

3 Department of Medical Oncology, "Euroclinic" Center of Oncology, 2 Vasile Conta Str., 700106 Iaşi, Romania

4 Department of Surgery, "Grigore T. Popa" University of Medicine and Pharmacy, 16 University Str., 700115 Iaşi, Romania; dscripcariu@gmail.com

5 Department of Biophysics and Medical Physics-Nuclear Medicine, "Grigore T. Popa" University of Medicine and Pharmacy, 16 University Str., 700115 Iaşi, Romania; cipriana.stefanescu@yahoo.com (C.S.); catistolniceanu@yahoo.com (C.R.S.)

6 Physics Department, "Gheorghe Asachi” Technical University, Prof. Dr. Docent Dimitrie Mangeron Rd., No. 59A, 700050 Iași, Romania; m.agop@yahoo.com

7 Department of Medical Oncology, University of Medicine and Pharmacy, 200349 Craiova, Romania; cristilungulescu@yahoo.com

* Correspondence: volovatconstantin@gmail.com; Tel.: +40-746-110-096

$+\quad$ These authors contribute equally to this paper.

\begin{abstract}
Immunotherapy represents a promising strategy for the treatment of cancer, which functions via the reprogramming and activation of antitumor immunity. However, adverse events resulting from immunotherapy that are related to the low specificity of tumor cell-targeting represent a limitation of immunotherapy's efficacy. The potential of nanotechnologies is represented by the possibilities of immunotherapeutical agents being carried by nanoparticles with various material types, shapes, sizes, coated ligands, associated loading methods, hydrophilicities, elasticities, and biocompatibilities. In this review, the principal types of nanovectors (nanopharmaceutics and bioinspired nanoparticles) are summarized along with the shortcomings in nanoparticle delivery and the main factors that modulate efficacy (the EPR effect, protein coronas, and microbiota). The mechanisms by which nanovectors can target cancer cells, the tumor immune microenvironment (TIME), and the peripheral immune system are also presented. A possible mathematical model for the cellular communication mechanisms related to exosomes as nanocarriers is proposed.
\end{abstract}

Keywords: immunotherapy; nanomedicine; nanotechnology; nanopharmaceuticals; nanoparticles; bioinspired nanovectors

\section{Introduction}

A malignant cell can harbor more than 11,000 genomic mutations in addition to new tumor-associated antigens (TAAs), including antigens produced by oncogenic viruses, altered glycoproteins, glycolipids, or oncofetal antigens [1]. These new tumor-associated antigens can be presented on cell surfaces along with major histocompatibility complex (MHC) molecules. The role of the immune system in cancer has been underestimated for many decades because tumor cells suppress the immune response by enhancing negative regulatory pathways involved in immune homeostasis or adopting features that prevent 
detection by the immune system. Two well-known checkpoints are cytotoxic T-lymphocyte protein 4 (CTLA4) and programmed cell death protein 1 (PD-1). CTLA4 has the role of inhibiting $\mathrm{T}$ cells, being in competition with the co-stimulatory molecules CD28 and CD86. PD-1 is a cell-surface receptor that is expressed by $\mathrm{T}$ cells, binding to the ligands PD-L1 and PD-L2. These ligands are expressed in a variety of cells, though PD-L2 is mainly expressed on dendritic cells in normal tissues [2-5], and antibodies that inhibit the interaction between PD-L1 and PD-1 produce clinical responses in a wide range of solid and hematologic malignancies [6] (Figure 1).

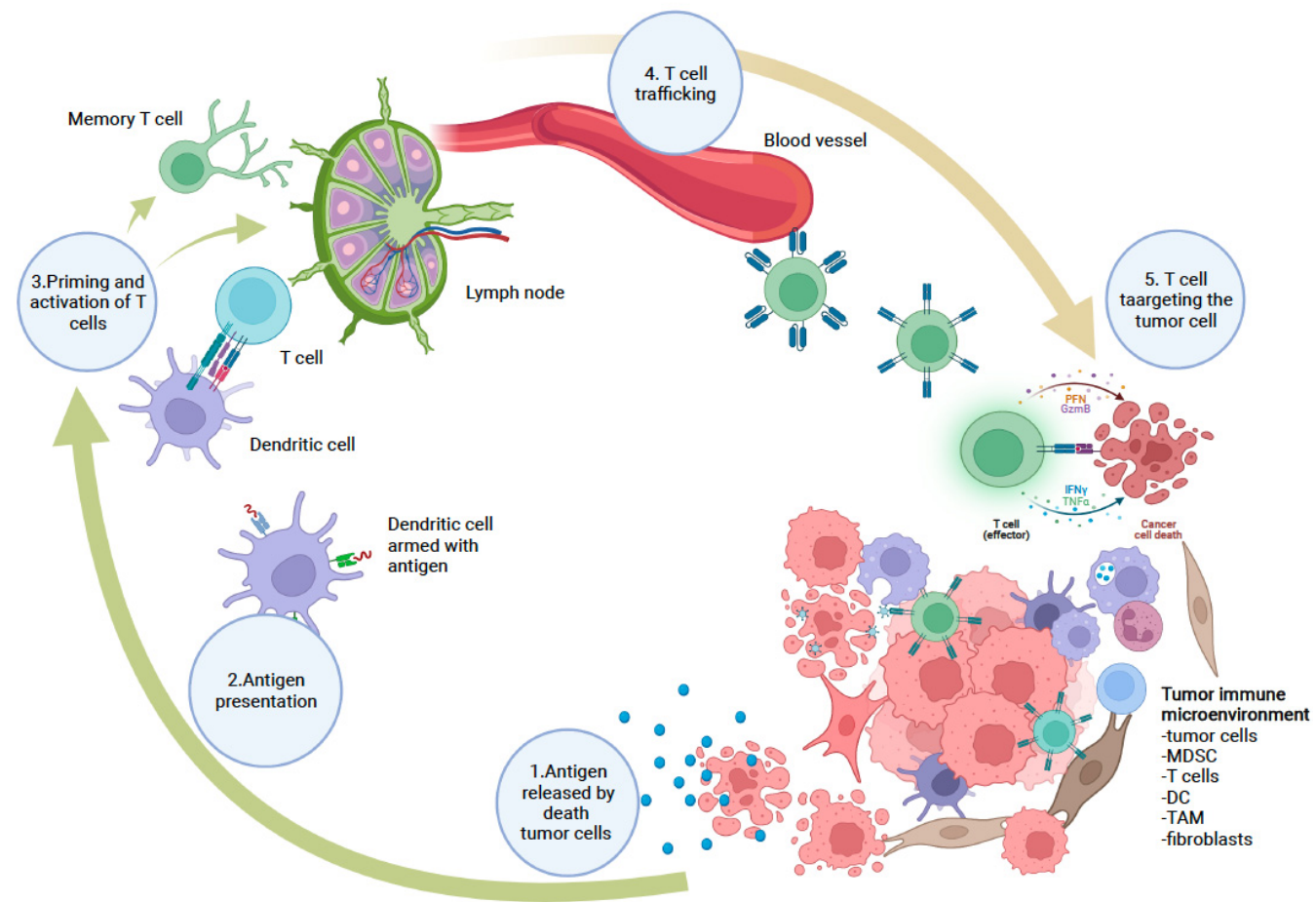

Figure 1. Process of antigen release by the tumor cell is followed by processing and presentation by APCs and activation of effective immune cells. T cells are trafficking and infiltrating the tumor tissues, being activated the immune cells from the TIME (tumor-infiltrating microenvironment) (created with www.BioRender.com).

Cancer immunoediting is a dynamic process consisting of three main phases: elimination, equilibrium, and escape. The elimination phase represents a modern vision of cancer immunosurveillance, where the molecules and cells with innate and adaptative immunity cooperate to identify the presence of developing tumors and eliminate them. Sometimes, variants of tumor cells may not be completely destroyed but enter an equilibrium phase in which the immune system controls tumor cell growth. The components of the immune system that participate in the elimination phase include cytokines (IFN- $\alpha / \beta$, IFN- $\gamma$, IL-12, and TNF), dendritic cells, macrophages, cells of innate immunity, such as NK or NKT cells, cells of adaptive immunity (CD4 ${ }^{+}$and $\mathrm{CD}^{+} \mathrm{T}$ cells), and immune effector molecules (perforin and TRAIL). The mechanisms for alerting the immune system to the presence of a developing tumor have not been fully characterized. It is supposed that a developing tumor stimulates the production of "danger signals", which are cytokines, such as type I IFNs, that activate dendritic cells, natural killer cells, and macrophages. The equilibrium phase is the second phase of cancer immunoediting, where the innate immune system cannot eliminate cancer cells, but keeps them in a state of immune-mediated tumor dormancy. The tumor cells and host immune system exist in a dynamic balance, where the immune system does not fully eradicate the heterogeneous tumor. Some of the tumor cells evade immune-mediated recognition and destruction [7]. A dramatic result of immunoediting is represented by tumor escape from immune control. The escape phase can be considered 
as a failure of the immune system to eliminate or control the cancer cells, enabling the survival of cell variants, which grow in an unrestricted manner. The immune phenotypes of the TME include both adaptive and innate immune cells that have a major influence on immunotherapy, and they are classified into three principal phenotypes: the immunedesert, immune-excluded, and inflamed phenotypes. The immune-desert phenotype (lacks antitumor immune cells) is characterized by immunological tolerance (losing the response to antigen presentation), ignorance (lack of antigens), and a lack of $\mathrm{T}$ cell priming [8]. These tumors include pancreatic and prostate cancers, and have poor responses to immune checkpoint inhibitors (ICI) and worse outcomes compared with other phenotypes due to the lack of pre-existing cytotoxic T cells and a poor clonal repertory of T cell receptors. In the immune-excluded phenotype, the immune cells from the tumor periphery or stroma are hampered by extravascular stroma and immature vessels. Moreover, the expression of transforming growth factor- $\beta$ (TGF- $\beta$ ) and the density of cancer-associated fibroblasts (CAFs) are enhanced $[9,10]$. Tumors of this phenotype are more sensitive to immune checkpoint inhibitors (ICI) than those with immune-desert phenotypes due to the existence of the $\mathrm{CD} 8^{+} \mathrm{T}$-effector-cell phenotype in the stroma, which can proliferate and become active. The third phenotype is the inflamed phenotype, where proinflammatory cytokines are expressed by $\mathrm{T}$ cells from the parenchyma, representing a failure of the antitumor immune response [11]. Although a large number of $\mathrm{T}$ cells with receptors against tumor-associated antigens are present, immune cells suppressed by hypoxia are also abundant. Examples of tumors with this phenotype are non-small-cell lung cancer and melanoma. This phenotype is considered to have the most potential in terms of sensitivity to ICI [12].

Superposed on the three main phenotypes of TME described above, the classification of tumors into two categories of "hot" and "cold" tumors was proposed, referring mainly to $\mathrm{T}$ cell infiltration, and the classification of these tumors into four categories was recently suggested, namely, into hot, altered-excluded, altered-immunosuppressed, and cold [13]. This concept for patient stratification is related to the type, location, and density of immune cells within a tumor site, and it can provide more accurate information than the classical TNM system for any type of cancer [14,15]. The classification into "hot" and "cold" tumors led to the development and implementation of the Immunoscore, which is a robust, consensus-based, standardized scoring system [16-18]. Cancer immunotherapy is focused on developing agents that promote strategies for the recognition and destruction of tumor cells by the immune system and represents a new alternative to classical therapies [19-22].

Classical cancer immunotherapy can be classified into (a) synthetic immunotherapy, involving programming to initiate new immune responses directed toward targets expressed by tumors, such as monoclonal antibodies (MoAbs) and chimeric antigen receptors (CARs), and (b) molecules designed to enhance natural immune responses, such as immune checkpoint inhibitors (ICIs) [23].

Compounds targeting PD-1 and CTLA-4 are the best-known immune checkpoint inhibitors that suppress $\mathrm{T}$ cell responses to cancers and target the tumors to enable antitumor immunity. To date, 14 different immunomodulators-seven checkpoint inhibitors, four cytokines, two adjuvants, and a small molecule with immunomodulatory properties-have been approved by regulatory agencies (FDA, EMA, NICE) for the treatment of more than a dozen major cancer types.

Other ICI therapies are currently in various stages of clinical testing for many different tumor types. Camrelizumab, pidilizumab, sintilimab, BMS-936559 (MDX-1105), and toripalimab (JS001) are some examples of those undergoing clinical trials and being investigated for their efficacy and safety profiles [24-27].

\section{Mechanisms of Resistance to Immune-Checkpoint Blockades in Cancer}

The heterogeneity of tumors and the complex immune microenvironment represents an important issue for treatment efficacy and is related to variations in the immune system that occur from individual to individual [28]. Immunotherapeutic resistance is classified as either primary (intrinsic) or acquired (extrinsic) resistance. Primary resistance represents 
a non-response of cancer to an immunotherapeutic strategy [29,30]. Intrinsic resistance involves the hyperprogressive diseases (HPDs) that causes the alteration of chromosome 11 region 13, (MDM)2/4 gene amplification, and epidermal growth factor receptor (EGFR) gene mutation [31,32]. TME alterations (polarization of macrophages) and a low tumoral mutational burden (TMB) are other factors influencing resistance [33-35]. The extrinsic mechanisms of resistance to immunotherapy are related to tumor-infiltrating lymphocytes (TILs) in the TME [36-38]. It was reported that the infiltration of immunosuppressive cells (Tregs, MDSCs, TAMs) in the TME is always associated with immunosuppression [39]. The "cold tumors" characterized by immunosuppressive tumor stroma are usually associated with a low mutational burden and a low neoantigen presence [40]. Tumor-associated TLSs are associated with good prognosis in the majority of cancer types, demonstrating the possibility to promote a systemic and long-lasting antitumor response [41].

\section{Bioactive Nanoparticles Designed to Modulate Cancer Immunotherapy}

Nanoscience is considered an "enabling technology" that impacts various fields of research and everyday life. This term initially included nanomedicine, also termed nanotechnology, which includes nanoparticles (NPs), but the expansion of the field of molecules that carry medicines has led to the emergence of the new and vastly more appropriate term nanovectors. The specific targeting of cancer tumors is the key to increasing treatment efficacy while reducing detrimental off-target effects and represents a major scientific issue. In recent years, vectorization approaches have expanded with the discovery of new families of nanovectors (with dimensions from 1 to $1000 \mathrm{~nm}$ ) created by chemical engineering (e.g., nanoparticles) or related to the biological world (e.g., viruses, bacteria, and extracellular vesicles) [42].

Drug development has become more complex, and efficient vectorization will improve the safety and efficacy of cancer therapies, representing a turning point in cancer treatment, experiencing a second birth after having been neglected for years. An interplay between cancer nanomedicine and immunotherapy can actually be described and has been demonstrated in multiple preclinical studies. Various types of materials have been tested for biomedical applications, including polymers, lipids, carbon structures, metals, and other organic and inorganic materials that can be used for nanopharmaceutical formulations, all of which have different features. The delivery of bioactive molecules using NPs has the potential to meet the goals of increasing the therapeutic efficacy and reducing the side effects of these molecules through improved pharmacokinetics and biodistribution.

There are various applications for which NPs can be used to enhance the efficacy of cancer immunotherapy. These include the delivery of antigens and adjuvants as vaccines, and the delivery of molecules and antibodies targeting specific cells, such as APCs or dendritic cells whose interaction modifies the tumor microenvironment.

The sizes of nanoparticles must range from 1 to $100 \mathrm{~nm}$, and they must also have high surface-area-to-volume ratios and advantageous delivery kinetics [43]. Small nanoparticles $(<10 \mathrm{~nm})$ can be frequently cleared by the kidneys, whereas larger nanoparticles, larger than $200 \mathrm{~nm}$, are more likely to be fenestrated in the spleen in addition to showing variable intratumoral distribution depending on regional blood flow. In addition, nanoparticles must have non-antigenic coatings to avoid triggering an immunogenic response in the host, as well as an enhanced ability to accumulate via passive targeting into highly angiogenic tumors. Another critical design parameter is the particle shape, which influences how a nanoparticle moves within the blood circulation, enters the cells, and stimulates an immune response [44]. Initial formulations were composed of nanoparticles with spherical shapes, but later advantages in nanoparticle engineering rendered the emergence of a new portfolio of possible shapes that include rods, prisms, cubes, stars, and disks. Asymmetric nanoparticles can also be manufactured and may show such advantages as enhanced nanoparticle penetration and distribution inside solid tissues and tumors [43]. It has been suggested that the Th1/Th2 polarization of the immune response is influenced by the particle shape. An important issue is related to the charging of NPs by loading moieties 
onto the particle surfaces via electrostatic interactions. Cationic nanoparticles can generate acute systemic toxicity and stimulate acute inflammation. A suggested mechanism could be that the cationically charged polymers used to construct nanoparticles can trigger patternrecognition receptors in immune cells [45]. Another property of NPs that plays a critical role in their biodistribution, cellular uptake, cellular association, and immune response is ligand density. Ligand conjugation to a nanoparticle, like the functionalization of mesoporous silicon nanoparticles with amines, can reduce systemic cytotoxicity [46]. In folate-targeted liposomes, it was observed that the internalization and externalization rates for a targeted receptor affected the optimal ligand density, which is critical for maximizing nanoparticle uptake. The flexibility of a nanoparticle can also modify antibody-mediated targeting, phagocytosis, and endocytosis. It was reported that particle endocytosis occurred more rapidly with flexible nanoparticles [47-49]. In conclusion, certain characteristics must be taken into account when designing an appropriate nanoparticle.

\subsection{Shortcomings in Nanoparticle Delivery and Efficacy}

The main factors that influence the targeting of NPs in tumors are the physiochemical properties of nanoparticles, which are influenced by such factors as the size; the shape; coating with tumor cell-targeting antibodies, aptamers, peptides, and/or small molecules that are able to interact with malignant cells; the properties of the tumor, such as the tumor type, size, and stage; and the influence of the mononuclear phagocytic system (MPS). The MPS comprises the spleen, liver, bone marrow, lymph nodes, skin, and other organs that contain resident phagocytic cells, such as macrophages. Macrophages from the MPS organs are derived from circulating monocytes. The nanoparticles are sequestered mainly by the liver and the spleen.

In the liver, the macrophages include Kupffer cells and motile macrophages and are located in liver sinusoids. The NPs flowing through the liver capillaries are recognized by the scavenger receptors of Kupffer cells and engulfed by them. The types and chemistry of NPs decide their fate; large inorganic NPs reside in Kupffer cells for a long time, whereas organic particles are rapidly degraded and eliminated [50]. The spleen contains macrophages that are involved in erythrocyte degradation in the red pulp, while the white pulp contains metallophilic macrophages and is involved in clearing apoptotic cells [51]. The main mechanism by which macrophages sequester NPs is phagocytosis, but this can also occur by clathrin- or caveolin-mediated endocytosis [52]. Macrophages sequester nanoparticles by phagocytosis, micropinocytosis, endocytosis, and other mechanisms. Low-density lipoproteins, nanoparticles, and bacteria are taken up through scavenger receptors [53].

Delivery issues are a major barrier to nanoparticle carriers, which encounter various physical and biological barriers (e.g., flow and shear forces, diffusion, phagocytic activity, and renal clearance) that influence their access to target tissues and cells [54-58].

The mononuclear phagocytic system (MPS) and the renal clearance pathway represent two factors that influence the accumulation of nanocarriers in tumor cells. The MPS can be defined as a network of organs (mainly the liver and spleen) containing phagocytic cells that take up nanoparticles, while the renal system is a filter that blocks nanoparticles larger than $5.5 \mathrm{~nm}$ in diameter.

Wilhelm et al. reported that a median of $0.7 \%$ of the injected dose (ID) of nanoparticles accumulates into a tumor, suggesting that only 7 out of 1000 injected nanoparticles effectively target a solid tumor in a mouse model [59].

The delivery of nanoparticles to tumors is influenced by specific (active) and nonspecific (passive) targeting. Specific targeting involves the functionalization of the nanoparticle surface using ligands that act as alternative target sites, and targets may include tumoral blood vessels, the extracellular matrix, or intracellular targets.

Nonspecific targeting is based on the coating of the nanoparticle with anti-fouling and/or stabilizing agents. The actual view is that nanoparticles cross the tumor vascular barrier through intercellular gaps and become trapped in the tumor due to pressure gener- 
ated by poor lymphatic drainage-a process termed "enhanced permeability and retention" (EPR) - and are further intratumorally retained via active targeting [60,61].

Once nanoparticles arrive in tumor blood vessels, some of them extravasate into the tumor microenvironment.

When nanoparticles are administered to tumor-bearing animals, they rapidly pass from the systemic circulation into the tumor vasculature, which is highly abnormal, with zones of both rich and poor vascular density, hierarchical disorganization, irregular branching and a serpentine structure, and vascular malformations with arteriovenous shunts [62]. The tumor vascular density is generally the highest at the tumor/host interface; in contrast, the central portions of tumors tend to be less well vascularized and often exhibit zones of necrosis owing to insufficient blood supply [62]. At least five distinctly different types of tumor blood vessels have been described: mother vessels (the first angiogenic type of blood vessel with abnormal hyperpermeability to plasma proteins), feeding arteries, glomeruloid microvascular proliferations (GMPs), capillaries, and draining veins.

Nanoparticles cross mother vessels and enter the tumor compartment, where the blood flow is sluggish, allowing the diffusion of nanoparticles out of the vessel and into the extracellular matrix of the tumor [63]. Some mechanisms for the extravasation of nanoparticles inside the tumor have been described. One is intercellular extravasation, where nanoparticles extravasate from the tumor blood vessels into the tumor microenvironment through gaps between endothelial cells. There is an alternative hypothesis (transcellular extravasation) where nanoparticles can extravasate into tumors via a transendothelial cell pathway [64]. The possibility of studying the transport of nanoparticles through intercellular gaps via the EPR effect has been heavily emphasized.

Once the nanoparticles have crossed the vascular barrier, they penetrate the tumor microenvironment, where they have to overcome biological barriers. After extravasation from the tumor vasculature, nanoparticles interact with components of the tumor stroma, such as nonmalignant fibroblasts, immune cells, and pericytes, and with elements of parenchyma (tumor cells). The heterogeneity of tumors is related to the parenchyma and stromal cells, and also to the ratio of support and secreted proteins. The pressure of the interstitial fluid in the tumor is 10-40 times higher than that in normal tissues, thus generating pressure gradients and heterogeneous flow in the interstitium. This pressure can modify the distribution and transport of macromolecules, drugs, and nanoparticles inside the tumor [65-67]. The increased pressure of the interstitial fluid causes high flow of interstitial fluid to the stroma and lymphatic vessels, and this process is strongly correlated with lymphangiogenesis, invasiveness, and metastasis [68].

\subsection{Modulation of Nanovector Efficacy}

The major factors that modulate the efficacy of nanopharmaceuticals are protein coronas, microbiome modulation, and the EPR effect. Protein coronas (PCs) refer to the inappropriate absorption of proteins onto the surfaces of NPs, which results in the NPs having different biological identities. These different identities are responsible for the failure of nanoparticle-based immunotherapy, and PC formation results in the generation of two types of responses: a nonresponse (immune blinding), promoted by the partial or total coverage of the antigens by the $\mathrm{PC}$, and an uncontrolled response (immune reactivity), with a hyperresponse of the immune system against the NP $[69,70]$. Immune blinding was described by Shanehsazzadeh et al., who observed that, in an in vivo mouse model, NPs showed higher distribution in the blood and muscle than in tumors. The conclusion was that the targeting molecules are covered by PCs, resulting in reduced in vivo tumor uptake, and the degree of immune blinding is sometimes related to the different PCs that are formed. PEGylation can reduce, but not eliminate, PC formation [71,72]. The immune-blinding process can be avoided by changing the physicochemical properties of the NPs [73]. The uncontrolled (immune reactivity) response involves the triggering of excessive immune activity, which is commonly related to a high production of proinflammatory cytokines or complement (C3) activation [74,75]. Biocompatible materials, such as zwitterionic polymers 
or hydrophilic nanoparticles, can be used to decrease protein adsorption and thus avoid complement activation [76].

Recently, cell-membrane coatings were developed to enable the camouflage of NPs to avoid immune clearance and allow complement activation [77]. A cell membrane coating based on red blood cell (RBC) membranes or PEG camouflages the particles from macrophage uptake, favoring their circulation for longer periods and thereby increasing their chances of accumulating in the tumor [78-80].

After being injected into the body, nanoparticles undergo a transformation of molecular identity from a synthetic identity to a biological identity, which includes an acquisition, after the interaction with the body's fluids of new physicochemical properties [81]. The new biological identity causes certain interactions with immune system cells, especially macrophages [82].

The heterogeneity of the response to immune treatment can sometimes be explained by the influence of gut microbiota, with the supposition that a large number of microorganisms can have a modulatory effect on the functions of immune cells, especially in the case of Tregs and $\mathrm{CD}^{+}$and $\mathrm{CD} 8^{+} \mathrm{T}$ cells. Some bacteria, such as Bifidobacterium longum, Bifidobacterium adolescentis, Lactobacillus species, and Parabacteroides merdae, have been linked to the response to anti-PD-1 treatment, in which they are involved in various mechanisms, such as elevating IFN- $\gamma$ secretion, enhancing DC function, and increasing the number of CD8 ${ }^{+}$tumor-infiltrating $\mathrm{T}$ cells $[83,84]$.

The enhanced permeability and retention (EPR) effect was initially studied on inflammation [85] and represents a correlation of the anatomical and pathophysiological features of the host with the characteristics of solid tumors. The features of the host consist of vascular architecture, or an inadequate secretion of various mediators (bradikinine, carbon monoxide, and vascular endothelial growth factor).

The explanation for this phenomenon is that, in order for tumor cells to grow rapidly, they must generate new blood vessels via VEGF or other growth factors, since they are dependent on having a blood supply. The newly formed tumor vessels have poorly aligned and defective endothelial cells with wide fenestrations, lacking a smooth muscle layer, and having impaired receptors for angiotensin II and effective lymphatic drainage. As a consequence, the fluid transport dynamics become abnormal, especially for macromolecular drugs. The cells in the tumor stroma contain cells that play a crucial role in improving the efficiency of EPR-mediated tumor accumulation. Macrophages have a strong influence on the retention of nanomedicines, and tumor-associated macrophages (TAMs) can act as a nanoparticle depot and gradually release the payload to neighboring tumor cells [86].

The applicability of nanopharmaceuticals and bioinspired nanoparticles has been driven by the use of the EPR effect, as this phenomenon includes pathophysiological factors and biological processes encountered within the body. The exchange surface and the halflife in circulation are critical points of the efficiency of nanoparticles. The EPR effect has been used in the development of new strategies that have improved the effectiveness and safety of NP [87-91]. The applicability of nanopharmaceuticals and bioinspired nanoparticles has been driven by the use of the EPR effect, as this phenomenon includes pathophysiological factors and biological processes encountered within the body. The exchange surface and the half-life in circulation are critical points of the efficiency of nanoparticles. The EPR effect has been used in the development of new strategies that have improved the effectiveness and safety of NP [92,93].

\section{Types of Nanovectors for Improving Cancer Immunotherapy}

Nanopharmaceuticals are generally classified according to their physical and chemical properties, such as material type, shape, size, charge, and surface properties, and it is now generally accepted that all of these features influence their kinetics, biodistribution, cellular uptake, immunogenicity, and loading properties.

The nanovectors used in cancer immunotherapy can be separated into nanopharmaceuticals and bioinspired nanovectors. Pharmaceutical nanotechnology consists of 
nanosized products that can be transformed in different ways to enhance their characteristics, leading to improvements in terms of prolonged circulation, drug localization, drug efficacy, etc. [94].

Nanopharmaceuticals include polymeric NPs, lipid nanocarriers, metal NPs, mesoporous silica NPs (MSNs), exosomes, and carbon nanotubes (CNTs) (Table 1) [95-99]. Bioinspired nanovectors (nanobioparticles) include the following: extracellular vesicles, bacterial minicells, virus-like particles (VLPs), oncolytic viruses, and phage-display nanobioparticles (Table 2) [100-103].

Table 1. Examples of the nanopharmaceuticals used for immunomodulation in cancer therapy.

\begin{tabular}{|c|c|c|c|c|c|}
\hline $\begin{array}{c}\text { Nanovector } \\
\text { Type }\end{array}$ & $\begin{array}{c}\text { Nanovector } \\
\text { Family }\end{array}$ & Delivery Platforms & Mechanism of Action & Types of Cancer & References \\
\hline \multirow{10}{*}{$\begin{array}{c}\text { Organic } \\
\text { nanoparticles }\end{array}$} & PLGA & $\begin{array}{l}\text { PLGA transporting } \\
\text { TLR7/ } 8 \text { bi-specific } \\
\text { agonists }\end{array}$ & $\begin{array}{l}\text { Increased co-stimulatory } \\
\text { molecule expression and } \\
\text { antigen presentation via } \\
\text { MHC I by DCs }\end{array}$ & $\begin{array}{l}\text { Melanoma, } \\
\text { bladder, and } \\
\text { renal-cell } \\
\text { carcinoma }\end{array}$ & [104] \\
\hline & & $\begin{array}{l}\text { PLGA carrying siRNA } \\
\text { and } 8837\end{array}$ & $\begin{array}{l}\text { PLGA NPs with RNA } \\
\text { (siRNA) for knockdown } \\
\text { of STAT3 in DCs and } \\
\text { imiquimod, R837 for } \\
\text { activating DCs through } \\
\text { TLR7 }\end{array}$ & & [105] \\
\hline & & $\begin{array}{l}\text { PLGA-NP carrying } \\
\text { murine melanoma } \\
\text { antigenic peptides, } \\
\text { hgp100(25-33) and } \\
\text { TRP2(180-188) }\end{array}$ & $\begin{array}{l}\text { Increased MHC class I } \\
\text { expression and } \\
\text { enhanced tumor control, } \\
\text { DC maturation and } \\
\text { activation }\end{array}$ & & [106] \\
\hline & Dendrimers & 2G-03NN24 dendrimer & $\begin{array}{l}\text { Decreasing expression of } \\
\text { M2-polarization genes, } \\
\text { decreased STAT3 } \\
\text { activation }\end{array}$ & & [107] \\
\hline & Liposomes & $\begin{array}{l}\text { MgluPG + pDNA } \\
\text { liposome complexes } \\
\text { (lipoplex) }\end{array}$ & $\begin{array}{l}\text { Transfecting DC } 2.4 \text { cells } \\
\text { and inducing IFN- } \gamma \\
\text { protein production }\end{array}$ & & [108] \\
\hline & & $\begin{array}{l}\text { Liposomal encapsulated } \\
\text { agonists of STING }\end{array}$ & $\begin{array}{l}\text { Improving the cellular } \\
\text { uptake of cGAMP and } \\
\text { proinflammatory gene } \\
\text { induction }\end{array}$ & Melanoma, lung & [109] \\
\hline & & $\begin{array}{l}\text { PEGylated } \\
\text { YSK05-MEND }\end{array}$ & Gene silencing & $\begin{array}{l}\text { Subcutaneous } \\
\text { tumor }\end{array}$ & [110] \\
\hline & & $\begin{array}{l}\text { Liposome-protamine- } \\
\text { hyaluronic acid (LPH) } \\
\text { NP + siRNA }\end{array}$ & Knockdown of TGF- $\beta$ & Melanoma & [111] \\
\hline & \multirow[t]{2}{*}{ Micelles } & $\begin{array}{l}\text { Polymeric hybrid } \\
\text { micelles (PHMs) with } \\
\text { Trp2/PHM/CpG } \\
\text { co-delivery system }\end{array}$ & $\begin{array}{l}\text { Enhance antigen-specific } \\
\text { cytotoxic T-lymphocyte } \\
\text { activity }\end{array}$ & Melanoma & [112] \\
\hline & & $\begin{array}{l}\text { Galactose- } \\
\text { functionalized zinc } \\
\text { protoporphyrin IX } \\
\text { (ZnPP) grafted poly(l- } \\
\text { lysine)-b-poly(ethylene } \\
\text { glycol) polypeptide } \\
\text { micelles (ZnPP PM) }\end{array}$ & $\begin{array}{l}\text { Repolarization of TAMs } \\
\text { to antitumor M1 } \\
\text { macrophages }\end{array}$ & & [113] \\
\hline
\end{tabular}


Table 1. Cont.

\begin{tabular}{|c|c|c|c|c|c|}
\hline $\begin{array}{l}\text { Nanovector } \\
\text { Type }\end{array}$ & $\begin{array}{l}\text { Nanovector } \\
\text { Family }\end{array}$ & Delivery Platforms & Mechanism of Action & Types of Cancer & References \\
\hline \multirow{9}{*}{$\begin{array}{c}\text { Inorganic } \\
\text { nanoparticles }\end{array}$} & $\begin{array}{c}\text { Gold } \\
\text { nanoparticles }\end{array}$ & $\begin{array}{l}\text { CpG } \\
\text { oligodeoxynucleotide } \\
+ \text { GNPs }\end{array}$ & $\begin{array}{ll}\text { - } & \text { Delivering CgP } \\
\text { oligonucleotides } \\
\text { - } & \text { Promoting } \\
\text { infiltration of } \\
\text { macrophages and } \\
\text { DCs }\end{array}$ & & [114] \\
\hline & & $\begin{array}{l}\text { GNPs + model antigen } \\
\text { (BSA) CpG } \\
\text { oligodeoxynucleotides }\end{array}$ & $\begin{array}{l}\text { Activating the immune } \\
\text { response of } \\
\text { macrophages by } \\
\text { interacting with TLR9 } \\
\text { receptor }\end{array}$ & & [115] \\
\hline & Iron oxide NPs & $\begin{array}{l}\mathrm{Fe}_{3} \mathrm{O}_{4}-\mathrm{OVA} \\
\text { nanoparticle vaccine }\end{array}$ & $\begin{array}{l}\text { Promoting secretion } \\
\text { TNF- } \alpha, \text { IL- } 6 \text {, and IFN- } \gamma\end{array}$ & Colon & [116] \\
\hline & $\begin{array}{l}\text { Mesoporous } \\
\text { silica (MSNPs) }\end{array}$ & $\begin{array}{l}\text { XLMSNs + OVA + } \\
\text { CpG-ODN vaccine }\end{array}$ & $\begin{array}{l}\text { Inducing DC } \\
\text { maturation, enhancing } \\
\text { IL-12 and TNF- } \alpha\end{array}$ & & [117] \\
\hline & & $\begin{array}{l}\text { MSNPs + indoximod } \\
+ \text { oxaliplatin }\end{array}$ & $\begin{array}{ll}\text { - } & \text { IDO inhibition } \\
\text { - } & \text { Induction of } \\
& \text { immunogenic cell } \\
& \text { death }\end{array}$ & Pancreas & [118] \\
\hline & $\begin{array}{c}\text { Carbon } \\
\text { nanotubes } \\
(\mathrm{MWNTs})\end{array}$ & $\begin{array}{l}(\alpha \mathrm{CD} 40) \mathrm{S} \pm \\
(\mathrm{OVA}-\mathrm{CpG}) \\
\text { incorporated in MWNTs }\end{array}$ & $\begin{array}{l}\text { Enhancement of OVA } \\
\text { delivering specific } \\
\text { immune response }\end{array}$ & Melanoma & [119] \\
\hline & $\begin{array}{l}\text { Carbon } \\
\text { nanotubes }\end{array}$ & CNT-loaded Rg3 & $\begin{array}{l}\text { - } \quad \text { Suppress the } \\
\text { PD-1/PD-L1 axis } \\
\text { - } \quad \text { Enhance the levels } \\
\text { of IFN- } \gamma \text { and } \\
\text { interleukins-2, } 9 \\
10,22 \text {, and } 23\end{array}$ & $\begin{array}{l}\text { Triple-negative } \\
\text { breast cancer }\end{array}$ & [120] \\
\hline & $\begin{array}{c}\text { Graphene oxide } \\
\text { (GO) }\end{array}$ & $\begin{array}{l}\text { Graphene quantum dots } \\
\text { (GQDs) }\end{array}$ & $\begin{array}{l}\text { Inducing apoptosis, } \\
\text { autophagy, and } \\
\text { inflammatory response } \\
\text { in activated THP-1 } \\
\text { macrophages }\end{array}$ & & [121] \\
\hline & $\begin{array}{l}\text { Reduced GO) } \\
\quad(\mathrm{rGO})\end{array}$ & PEG-rGO-FA-IDOi & $\begin{array}{l}\text { IDO inhibition and } \\
\text { PD-L1 blockade that } \\
\text { enhances TILs and } \\
\text { suppress Tregs }\end{array}$ & & [122] \\
\hline & & (IDOi/rGO nanosheets) & & & \\
\hline
\end{tabular}

Table 2. Examples of the bioinspired nanovectors used for immunomodulation in cancer therapy.

\begin{tabular}{|c|c|c|c|c|c|}
\hline $\begin{array}{l}\text { Nanovector } \\
\text { Type }\end{array}$ & $\begin{array}{l}\text { Nanovector } \\
\text { Family }\end{array}$ & Platform & Mechanism & Types of Cancer & References \\
\hline $\begin{array}{l}\text { Bacterial } \\
\text { minicells }\end{array}$ & Minicells & $\begin{array}{l}\text { Salmonella (S.) } \\
\text { Typhimurium T3SS }\end{array}$ & $\begin{array}{l}\text { T3SS deliver APC and } \\
\text { stimulate CD8 }{ }^{+} \mathrm{T} \text { cells }\end{array}$ & & [123] \\
\hline $\begin{array}{l}\text { Extracellular } \\
\text { vesicles }\end{array}$ & $\begin{array}{l}\text { Tumor-derived } \\
\text { exosome (TEXs) }\end{array}$ & SAV-exo + CpG-SAV-exo & $\begin{array}{ll}\text { - } & \text { Strong Th-1 } \\
\text { antigen-specific } \\
\text { immune response } \\
\text { - } \quad \text { Strong tumor- } \\
\text { specific CD4p and } \\
\text { CD8p T cell responses }\end{array}$ & Melanoma & {$[124,125]$} \\
\hline
\end{tabular}


Table 2. Cont.

\begin{tabular}{|c|c|c|c|c|c|}
\hline $\begin{array}{c}\text { Nanovector } \\
\text { Type }\end{array}$ & $\begin{array}{l}\text { Nanovector } \\
\text { Family }\end{array}$ & Platform & Mechanism & Types of Cancer & References \\
\hline & & $\begin{array}{l}\text { Adenovirus platform } \\
\text { (LOAd) with transgenes } \\
\text { (TMZ-CD40L and } 4 \\
\text { 1BBL) }\end{array}$ & $\begin{array}{l}\text { Targeting DCs, T cells, } \\
\text { and NK cells }\end{array}$ & Melanoma & [126] \\
\hline & $\begin{array}{c}\text { Dendritic } \\
\text { cell-derived } \\
\text { exosomes (DEX) }\end{array}$ & $\begin{array}{l}\text { DEX + MAGE tumor } \\
\text { antigen }\end{array}$ & 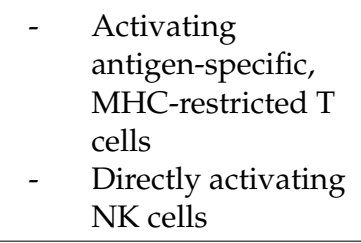 & NSCLC & [127] \\
\hline & & $\mathrm{DEX}+\mathrm{IFN}-\gamma$ & Activating NK cells & & {$[128]$} \\
\hline & $\begin{array}{l}\text { Ascites-derived } \\
\text { exosomes (Aex) }\end{array}$ & Aex + GM-CSF & $\begin{array}{ll}\text { - } & \text { CEA }(\mathrm{CAP}-1 \\
\text { peptide)-specific } \\
\text { IFN- } \gamma \text { release from } \\
\mathrm{CD} 8^{+} \mathrm{T} \\
\text { lymphocytes } \\
\text { - Promoting antigen } \\
\text { presentation and } \mathrm{T} \\
\text { cell activation }\end{array}$ & Colon & [129] \\
\hline $\begin{array}{l}\text { Virus-like } \\
\text { nanoparticles } \\
\text { (VLNs) }\end{array}$ & VLNs & VLN-sgPD-L1@Axi & $\begin{array}{ll}\text { - } & \text { Co-delivery } \\
\text { system to enhance } \\
\text { efficacy of } \\
\text { CRISPR/Cas9 } \\
\text { - Disruption of } \\
\text { PD-1/PD-L1 } \\
\text { pathway } \\
\text { - Reinvigoration of } \\
\text { T cells and TILs } \\
\end{array}$ & & [130] \\
\hline \multirow[b]{3}{*}{ Oncolytic viruses } & Picornavirus & $\begin{array}{l}\text { ECHO-7 strain of a } \\
\text { picornavirus }\end{array}$ & $\begin{array}{l}\text { Selectively infecting and } \\
\text { destroying cancer cells }\end{array}$ & Melanoma & [131] \\
\hline & Adenovirus & $\begin{array}{l}\text { Engineered adenovirus } \\
\text { H101 }\end{array}$ & $\begin{array}{l}\text { Interacting with normal } \\
\text { human gene p53 }\end{array}$ & Nasopharyngeal & [132] \\
\hline & $\begin{array}{l}\text { Herpes simplex } \\
\text { virus }\end{array}$ & $\begin{array}{l}\text { Herpes simplex virus } \\
\text { encoding GM-CSF }\end{array}$ & $\begin{array}{ll}\text { - } & \text { GM-CSF genes, } \\
\text { replacing virulent } \\
\text { ICP47 genes, } \\
\text { stimulating CD8 } \\
\text { cells, accumulation } \\
\text { of DC } \\
\text { Activating } \\
\text { JAK-STAT } \\
\text { pathways, } \\
\text { stimulating IFN } \\
\text { production } \\
\text { - Inhibiting Tregs } \\
\text { and MDSCs } \\
\text { - Stimulating the } \\
\text { production of } \\
\text { anti-Melan } \\
\text { A/IFN- } \gamma \text { T cells }\end{array}$ & Melanoma & [133] \\
\hline
\end{tabular}


Table 2. Cont.

\begin{tabular}{|c|c|c|c|c|c|}
\hline $\begin{array}{l}\text { Nanovector } \\
\text { Type }\end{array}$ & $\begin{array}{l}\text { Nanovector } \\
\text { Family }\end{array}$ & Platform & Mechanism & Types of Cancer & References \\
\hline & $\begin{array}{l}\text { Adenovirus } \\
\text { (Onc.Ad) }\end{array}$ & $\begin{array}{l}\text { CAR-T cells + } \\
\text { Cad-VECPDL1 }\end{array}$ & 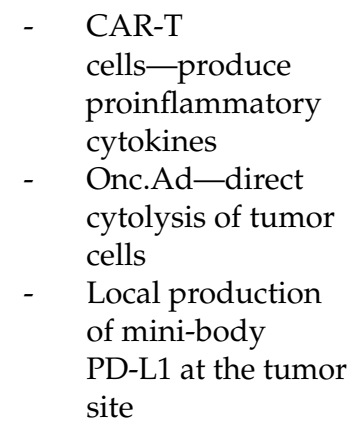 & Prostate & {$[134]$} \\
\hline \multirow{3}{*}{ Bacteriophages } & Bacteriophages & $\begin{array}{l}1 \mathrm{ZAP}-\mathrm{CMV} \text {-apoptin } \\
\text { recombinant NBP }\end{array}$ & $\begin{array}{l}\text { Transfection of the } \\
\text { human breast neoplastic } \\
\text { cells with the } \\
\text { nanobioparticles } \\
\text { carrying } 1 \\
\text { ZAPCMV-apoptin } \\
\text { construct }\end{array}$ & & {$[135]$} \\
\hline & & $\begin{array}{l}\text { Lambda-phage } \\
\text { nanobioparticles } \\
\text { containing enhanced } \\
\text { EGFP and E7 gene of } \\
\text { HPV type } 16\end{array}$ & $\begin{array}{l}\text { Gene delivery system } \\
\text { and vaccine } \\
\text { recombinant lambda } \\
\text { bacteriophages for gene } \\
\text { delivery }\end{array}$ & & {$[136]$} \\
\hline & & $\begin{array}{l}\text { TAA-mimic molecule } \\
\text { (mimotope) }\end{array}$ & $\begin{array}{l}\text { The mimotope triggers } \\
\text { the production of } \\
\text { anti-TAA Abs }\end{array}$ & & [137] \\
\hline
\end{tabular}

\subsection{Nanopharmaceuticals}

PLGA (poly(lactic-co-glycolic acid)) (Figure 2) is an FDA-approved polymer that is biocompatible and biodegradable, and can be used to encapsulate many biologically active compounds with low toxicity. PLGA microspheres can target the pathways for MHC class I and class II molecules and enhance DC maturation [67]. PLGA nanoparticles are nonspecifically taken up. PLGA nanoparticles have been designed for the transportation of cytokine agonists, siRNAs, or CpG-coated tumor antigens to enhance antigen uptake by DCs and trigger both CTL $\left(\mathrm{CD}^{+}\right)$and $\mathrm{Th}\left(\mathrm{CD}^{+}\right)$immune responses [138-140].

Colzani et al. reported the development of an efficient antibody delivery system that includes trastuzumab and doxorubicin in poly(lactic-co-glycolic) acid nanoparticles capable of affecting the regulatory signaling pathways of cancer cells and stimulating ADCC [141]. In vitro results showed that the PLGA nanoparticles were more suitable for targeting DCs than the PLGA microparticles, with a 10- to 100-fold increased efficiency in hD1 release from nanoparticles [142]. NPs were designed with a maximum density of monoclonal antibodies on the surface, which is responsible for the higher interleukin-10 (IL-10) production and enhanced antitumor response. Therefore, PLGA NPs containing antigenic peptides can target DCs for vaccine delivery, followed by the triggering of the cytotoxic $\mathrm{T}$ cell immune response, which blocks the immune-escape mechanism of tumor cells $[143,144]$. Tumor cells develop genetic and epigenetic alterations to prevent recognition and elimination by immune cells, promoting immune evasion. Gold nanoshells and anti-PD-1 peptide (APP)-loaded PLGA nanoparticles were intratumorally administered in one study, and an antitumoral effect at the primary tumor site was demonstrated, achieved in combination with photothermal therapy [145]. 


\section{Classes of Nanoparticles}

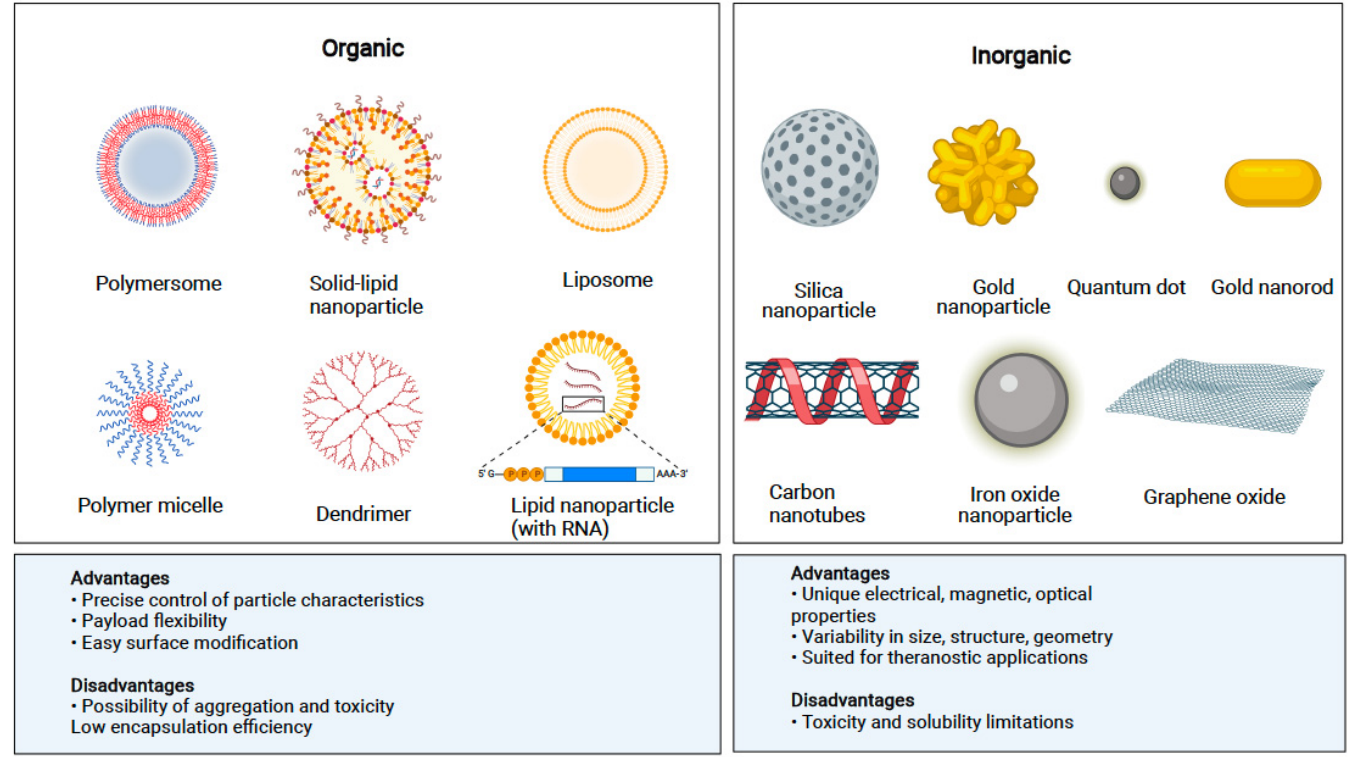

Figure 2. Classes of nanopharmaceuticals (created with BioRender-www.BioRender.com).

Dendrimers are broadly branched macromolecules composed of a core and cavities to entrap drugs. Dendrimers have well-defined chemical structures, water solubilities, and polyvalencies, properties that are suitable for drug delivery [146]. The direct interaction of dendrimers and immune cells has been described. Poly(phosphorhydrazone)dendrimers were found to selectively elevate the proliferation of natural killer cells with anticancer activity [64]. Dufes et al. reported tumor reduction by chemoimmunotherapy based on the use of dendrimers as carriers. The systemic administration of dendrimer nanoparticles containing a TNFA expression plasmid regulated by telomerase gene promoters (hTR and hTERT) results in transgene expression and the regression of remote xenograft murine tumors. In addition, a complex structure designed to contain a $\mathrm{CpG}$ oligonucleotide as an immune-stimulating agent and doxorubicin was demonstrated to be targeted by a prostate-specific membrane RNA aptamer [147].

Lipid nanocarriers are vesicles containing one or more bilayers of phospholipids that are characterized by high biocompatibility, and the following subcategories are included: solid-lipid nanoparticles, nanoemulsions, lipid nanocapsules, and liposomes. The liposome structure has many similarities with the cell membrane, in which hydrophobic tails of phospholipids cluster together while the heads are hydrophilic. The existence of hydrophobic and hydrophilic compartments allows the encapsulation and delivery of various compounds without affecting their properties, and they are thus considered an ideal drug-delivery system [148,149].

An effective treatment option involving the co-delivery of ovalbumin (OVA) and IFN-encoding pDNA to DCs via liposomes was described. There is a combined therapeutic effect of OVA and IFN-encoding pDNA that enhances the antitumor effect through CTL activation [150]. Using $\mathrm{pH}$-sensitive dextran liposomes, enhanced infiltration of $\mathrm{CD} 8^{+}$in the tumor was demonstrated. Curdlan and mannan are bioactive polysaccharides that can be used in the formulation of $\mathrm{pH}$-sensitive liposomes to improve $\mathrm{DC}$ activation. The liposomal delivery of cGAMP facilitates the improved activity of STING agonists, resulting in improvements in the immunological memory and rechallenging of tumor cells. Gene delivery for enhancing immunotherapy is represented by the delivery of RNA lipoplex (RNA-LPX) to DC cells that trigger in situ DC maturation. PEGylation is frequently used for the delivery of siRNA. An example is the pH-sensitive cationic lipid YSK05 that was developed as a PEGylated multifunctional envelope-type nanodevice (MEND), and it was demonstrated that this platform enhances gene silencing when administrated intratumorally [151]. 
Micelles are vesicular particles formed by the spontaneous aggregation of amphiphilic molecules, with many applications in cancer treatment as carriers. The synthesis of micelles is easier than that of other nanocarriers, and micelles are also biodegradable, nontoxic, and able to be intracytoplasmically delivered. They are used to carry ovalbumin (OVA) or regulate metabolism-related enzymes, such as IR780, which results in the inhibition of IDO (indoleamine 2,3-dioxygenase), followed by the activation of T lymphocytes and, consequently, the inhibition of distal tumor growth (abscopal effect). Zinc-protoporphyrin IX-grafted polypeptide micelles that target TAMs and stimulate the immune system were designed. The stimulation of T lymphocytes by the repolarization of TAMs was followed by tumor regression [152].

Gold nanoparticles (GNPs, AuNPs) can deliver antigenic proteins and gene oligonucleotides to specific sites. The surfaces of AuNPs can undergo covalent and noncovalent interactions with various biomolecules, such as DNA, peptides, and antibodies [153-155].

AuNPs were described to influence the nucleus, its subcompartments, and the mitochondria of cancer cells.

One of the major properties of GNPs is localized surface plasmon resonance (LSPR) that is sensitive to size, material geometry, dimensions, and the dielectric properties of the surrounding media. Consequently, GNPs have been produced in different shapes, such as nanospheres, nanoshells, nanorods (NRs), nanostars, nanocages, and core-shell structures. A series of $\mathrm{Au}-\mathrm{On}-\mathrm{AuNR}$ hybrid structures that are homometallic nanostructures in two new dimensions was also developed; their LSPR was effectively NIR-tuned within the visible NIR (near-infrared region) spectral range, rendering them excellent candidates for photothermal therapy [156].

In photothermal therapy, the absorbed light turns into heat, causing the irreversible distortion of DNA or cells [53]. If nanogold particles are used, there is an increase in light absorption at a certain wavelength, thus reducing the power of the laser for the photothermal removal of cancer cells. GNP-conjugated antibodies can be conjugated to monoclonal antibodies for targeting cancer cells when illuminated by light with a wavelength corresponding to the GNP wavelength [157]. The combination of AuNPs with photothermal ablation is a promising concept that is being researched in numerous different trials. Gold NPs have been used in delivering CgP oligonucleotides to macrophages and DCs followed by a regression in tumor growth. The delivery of adjuvants, such as OVA or $\mathrm{CpG}$, for immunotherapy was carried out using gold nanoparticles of different sizes and shapes, and $15 \mathrm{~nm}$ was found to be the size with the best efficacy for the immunotherapeutic delivery of antigens [155].

Iron oxide nanoparticles are potent carriers for vaccine delivery. They have a direct effect by polarizing immune cells, such as DCs and macrophages, increasing the immune response, or they can be used as a delivery system with OVA functioning as an immune potentiator [158]. The FDA have approved supplementation with ferumoxytol in mammary cancer due to an intrinsic therapeutic effect. In vitro, it was demonstrated that adenocarcinoma cells incubated together with ferumoxytol and macrophages could enhance caspase- 3 activity. Moreover, macrophages exposed to ferumoxytol could induce proinflammatory Th1-type responses in macrophages [159].

Mesoporous silica NPs (MSNs) are solid materials with a honeycomb-like porous structure containing hundreds of empty mesopores capable of absorbing large quantities of bioactive molecules [160]. Mesoporous silica materials can show diverse interactions with biosystems, with effects on various properties that contribute to biodegradation, biodistribution, toxicity, cellular uptake, and, more importantly, their interaction with immune cells [160].

Mesoporous silica materials are nontoxic and biodegradable under physiological conditions and can be released to tissues and excreted via renal clearance. Smaller particles and lower concentrations of mesoporous silica were demonstrated to affect smaller proportions of human monocyte-derived dendritic cells (MDDCs) in comparison to the use of larger 
particles and higher concentrations, which has led to their suggested use as a component of cancer vaccines [161].

A complete vaccine formulation using mesoporous silica (XLMSNs + OVA + CpGODN) was developed and successfully induced dendritic cell (DC) maturation with high levels of CD86 expression and increased secretion of proinflammatory cytokines, including IL-12 and TNF- $\alpha$. MSNs were found to be useful for transporting drugs and siRNAs, which can be co-delivered into the body and induce cytokine secretion [162,163].

Carbon nanotubes (CNTs) are cylindrical models composed of carbon that have demonstrated their potential in multiple ways, including as tumor-antigen nanocarriers. Frequently, the CNTs used are multiwalled carbon nanotubes (MWNTs), which were successfully used to co-deliver OVA and CpG to antigen-presenting cells (APCs) [164]. In addition, the photothermal ablation of primary tumors has been achieved with singlewalled carbon nanotubes. It was demonstrated that photothermal ablation could be used together with carbon nanotubes to trigger significant immune responses and, additionally, in combination with anti-CTLA-4 antibody therapy to prevent metastasis [165].

2D nanomaterials - the most popular 2D nanomaterials include those of the graphene family (graphene oxide (GO), reduced graphene oxide (rGO), graphene quantum dots, and graphene nanoribbons), black phosphorus (BP), layered double hydroxides (LDHs), transitionmetal dichalcogenides (TMDs), transition-metal oxides (TMOs), and MXenes [166-169]. Biointeractions between the immune system and nanomaterials, including 2D nanomaterials, affect the immune system, and it is essential to identify all the affected factors that are related to biological safety. The cytotoxicity of graphene was studied, and this includes examining the effects on membrane integrity, cell viability and morphology, DNA damage, reactive oxygen species (ROS) generation, gene expression, and uptake mechanisms. The interactions of graphene oxide with cells can lead to excessive ROS generation, which is involved in the mechanisms of aging, carcinogenesis, and mutagenesis [170,171]. Graphene nanoparticles can disrupt the mitochondrial membrane potential and increase intracellular ROS generation, triggering the activation of apoptosis via the mitochondrial pathway [172]. Moreover, DNA intercalation and cleavage mechanisms are induced by the interactions of graphene with cellular genetic material [173]. Reduced graphene oxide (rGO) is a 2D nanomaterial of the graphene family with a single atom layer arranged in a honeycomb lattice structure. With a unique surface characterized by functional groups, rGO can be highly loaded with genes, increasing the delivery efficacy.

rGO was accepted for application in both chemotherapy combined with photothermal therapy and immunotherapy combined with photothermal therapy. A platform including PEGylated rGO combined with iron oxide was developed by Wang et al. [173,174]. Another strategy for targeting multiple antitumor immune pathways to induce synergistic antitumor immunity was explored in vivo by Yan et al., involving the design of a platform that combined immunotherapy with PTT based on folic acid and a multifunctional IDO inhibitor loaded with reduced graphene oxide (rGO)-based nanosheets (IDOi/rGO nanosheets), which directly kill tumor cells under laser irradiation and trigger an in situ antitumor immune response. IDO inhibition and the PD-L1 blockade triggered the immune response, enhancing tumor infiltration by lymphocytes, including T cells and NK cells, and suppressing Tregs and the production of IFN- $\gamma$ in CT26 colon cancer cells [174].

Clinical research on nanopharmaceuticals for potentiating immunotherapy is currently at a point at which many have reached the clinical research phase, with promising results (Table 3).

\subsection{Bioinspired Nanovectors}

Bacterial minicells (Figure 3) are nanosized (100-300 nm in diameter) and originate from bacteria via abnormal cell division, and they have been used for the therapy of cancer, beginning several decades ago [185]. Minicells are nonliving, anucleated, nondividing cells that lack chromosomal DNA but contain RNA, ribosomes, peptidoglycan, proteins, and plasmids. Minicells still maintain other cellular activities, including mRNA translation, 
ATP synthesis, and the transcription and translation of plasmid DNA, but they have no possibility to grow or divide [186]. Some minicells have been used to deliver antigens, such as Salmonella (S.) Typhimurium T3SS, which was engineered into minicells. T3SS delivers antigens directly into the cytosol via the class I antigen presentation pathway (APC), stimulating antigen-specific $\mathrm{CD} 8\left(^{+}\right) \mathrm{T}$ cells $[187,188]$.

Table 3. Examples of ongoing clinical trials using nanovectors to enhance immunotherapy.

\begin{tabular}{|c|c|c|c|c|}
\hline Nanovectors & Indications & Clinical Stage & $\begin{array}{c}\text { Ref. Number } \\
\text { www.ClinicalTrials.gov }\end{array}$ & Reference \\
\hline PEGylated IL-2 + checkpoint inhibitor & Solid tumors & Phase I-III & $\begin{array}{l}\text { NCT02983045 } \\
\text { NCT03282344 } \\
\text { NCT03785925 } \\
\text { NCT03729245 } \\
\text { NCT03435640 }\end{array}$ & [175-177] \\
\hline $\begin{array}{c}\text { NBTXR3 activated by radiotherapy } \\
+ \text { anti-PD-L1 }\end{array}$ & Solid tumors & Phase I & NCT03589339 & {$[178,179]$} \\
\hline $\begin{array}{l}\text { Polymer with undisclosed payload } \\
\text { nanoparticles + chemotherapy }\end{array}$ & Solid tumors & Phase I & $\begin{array}{l}\text { NCT03781362 } \\
\text { NCT03953742 }\end{array}$ & [180-182] \\
\hline $\begin{array}{l}\text { Metallic-organic nanoparticles + IDO } \\
\text { inhibitor to enhance radiotherapy } \pm \\
\text { checkpoint inhibitors }\end{array}$ & Solid tumors & Phase I & NCT03444714 & [183] \\
\hline $\begin{array}{c}\text { Lipid nanoparticles to deliver mRNA } \\
\text { encoding OX-40L }\end{array}$ & $\begin{array}{l}\text { Solid } \\
\text { tumors/lymphoma }\end{array}$ & Phase I/II & NCT03323398 & [184] \\
\hline
\end{tabular}

Extracellular vesicles (EVs) are a heterogeneous group of small membrane-bound vesicles that function as key mediators of many pathophysiological processes, with many advantages for drug and gene delivery and therapeutic capacities [189]. EVs are secreted by different cells, including dendritic cells (DCs), epithelial cells [190], neural cells [191], mesenchymal stem cells (MSCs) [192], and tumor cells (tumor-derived exosomes) [193]. EVs are also found in the serum, saliva, urine, and other bodily fluids [194]. Subtypes of EVs, including ectosomes, exosomes, microvesicles, membrane vesicles, and apoptotic bodies, have been described, which are isolated from different sources, and each type may have distinct biogenesis pathways, given that their biological origin is uncertain in most cases [195]. Proteomic evidence suggests that an EV core protein signature is commonly shared between EVs of diverse parent-cell origins $[196,197]$. EVs already have applicability in tumor immunotherapy due to possessing some advantages, such as lower toxicity and resulting in more frequent and durable responses.

Exosomes are a subtype of EVs that are secreted by the vast majority of cell types, with functions of intercellular communication and the transportation of proteins, lipids, and nucleic acids between cells and organs, thereby being involved in the progression of cancer. Exosomes are considered sophisticated vesicles involved in various physiological and pathological processes in the immune system based on their role as modulators, mediators, or activators.

A subgroup of exosomes, tumor-derived exosomes (TEXs), are used to load and deliver synthetic drugs, silencing RNAs and microRNAs. CD47v limits the ability of macrophages to devour tumor cells by binding to SIRP $\alpha$, serving as a "do not eat me" signal [198]. Exosomes that carry SIRP $\alpha$ variants may antagonize the interaction between CD47 and SIRP, enhancing tumor phagocytosis and enhancing an effective antitumor $\mathrm{T}$ cell response.

The secretion of exosomes is a characteristic of both lymphoid and myeloid lineages, and also of many types of cells involving the TME and cancer cell secretion of tumorderived exosomes that contain growth factors and microRNAs (e.g., miR-423-5p and miR-675) [199,200]. 


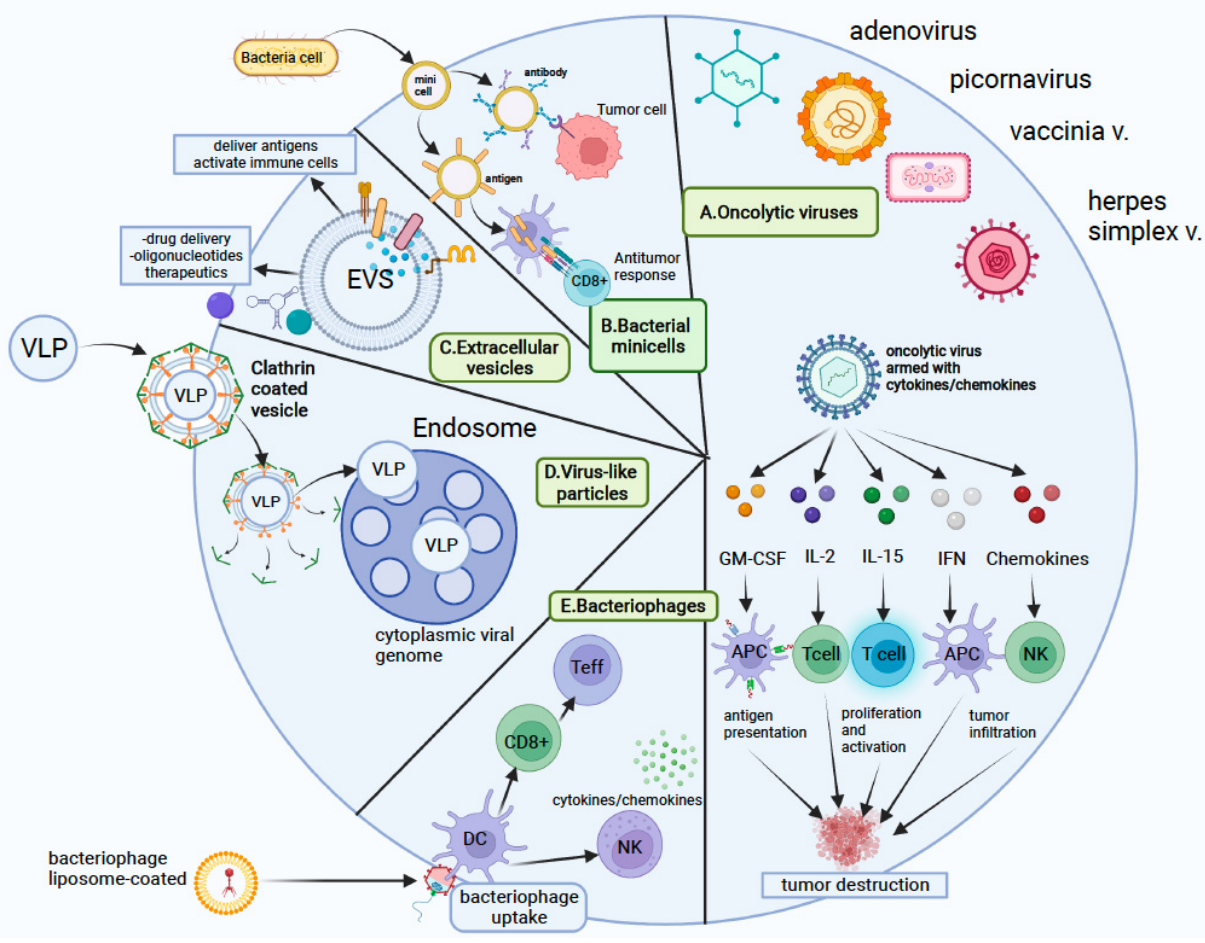

Figure 3. Bio-inspired nanovectors: A. Tumor destruction by cytokine/chemokine-armed oncolytic viruses. GM-CSF helps in antigen presentation through the recruitment and activation of dendritic cells and macrophages; B. Minicells with bacterial origin encapsulate the chemotherapeutic drugs, shRNA, or toxin protein. Minicells bind to the receptors of the cancer cells via the bi-specific antibody conjugated on the minicell's surface. Minicells enter the cancer cell, where they release drugs with an anti-cancer effect. Engineered minicells can produce antigen, which activates the anti-tumor immune response; C. EVS deliver antigens to activate the immune cells or can deliver anti-tumor drugs D. VPL are attached to host receptors, inducing the binding of adaptor proteins to clathrin and releasing of the clathrin-mediated vesicles that deliver to early endosomes; E. Bacteriophages can be encapsulated into polymers and stimulate the DCs, triggering an immune response (created with Biorender-www.BioRender.com).

A combination of GM-CSF treatment and exosomes derived from ascites has demonstrated its potency in enhancing tumor-specific cytotoxic T cells, which determined the responses in a phase I trial [201]. The safety and therapeutic efficacy of autologous exosomes derived from dendritic cells carrying tumor MAGE peptides were demonstrated in another phase I trial, resulting in the improvement of antitumor immunity, and extending the disease responses in patients with advanced non-small-cell lung cancer (NSCLC) [202].

In a phase II clinical trial, exosomes loaded with IFN and MHC class I and II proteins were administered to patients with advanced NSCLC, resulting in an observed improvement in the NK cell-mediated antitumor immune response, with prolonged overall survival and progression-free survival in 50\% of the patients [203]. Chimeric antigen (CAR)-T cell-derived exosomes also resulted in an improvement in clinical responses and benefits in controlling immune-related adverse events [204-206].

Virus-like particles (VLPs) were designed to mimic animal, plant, or bacterial viruses, but lack the property of replicating in human cells. VLPs are suited to the transport and delivery of nucleic acids due to their viral nature [207], but were developed as empty capsids that can also transport other types of molecules. VLPs have a structure that allows genetic and chemical engineering. It was demonstrated that nonhuman virus-based VLPs do not recognize human cell receptors and require genetic or chemical retargeting to malignant cells. The retargeting of VLPs using cancer-specific peptides, aptamers, or other molecules, or by enveloping VLPs with exogenous proteins, is possible. VLPs derived 
from human pathogens exhibit efficient gene transfer within human cancer cells. VLPs, being immunogenic, can enhance immune responses and can be engineered as vaccines to target immune cells. Lizotte et al. reported the use of a VLP-based vaccine based on cowpea mosaic virus as a delivery vehicle and also as an immunotherapeutic agent. VLPs specifically target TME cells and tumor cells and can be used as a nanocarrier for tumor antigens and drugs [208].

Oncolytic viruses (OVs) are viruses that have properties allowing them to infect and kill cancer cells. OVs are involved in the regression of tumors through target replication in tumor cells, promoting immunogenic cell death and host antitumor immunity. A large number of both DNA and RNA viruses have undergone preclinical studies as potential candidates for OV drug development. In OV selection, viruses with natural tropism and predilection for preferential replication in tumor cells are preferred, as are those demonstrating enhanced replication in tumor cells. The mechanisms of OVs involve direct oncolytic activity and the promotion of the immunogenic cell death of tumor cells, generating a tumor-reactive $\mathrm{T}$ cell response, especially for $\mathrm{CD}^{+}$and $\mathrm{CD} 8^{+} \mathrm{T}$ cells $[209,210]$. OVs can be used as platforms for the specific delivery of immune-stimulatory transgenes into the tumor niche (chemokines, cytokines, ICIs, co-stimulatory ligands, and tumor-associated antigens) to trigger immune-cell activation and transform the immunosuppressive TME [211]. Preclinical studies have demonstrated the use of engineered OVs in the delivery of a variety of genes that help in promoting the induction of immune responses, cytotoxic killing of tumor cells, suppression of tumor neoangiogenesis, radiosensitization, and other strategies [212,213]. For the delivery of the virus to patients with cancer, intratumoral (IT) injections were initially studied, but intravenous administration can also be considered, which allows the targeting of multiple metastatic lesions.

In the last years, an abundance of clinical trials related to OV were published involving numerous viruses as strategies of treatment in various cancers. There are three oncolytic viruses approved for cancer therapy: Rigvir (a picornavirus) and Talimogene laherparepvec (a herpes simplex virus type 1) approved for the treatment of malignant melanoma, and a modified adenovirus H101 combined with cytotoxic chemotherapy for the treatment of nasopharyngeal carcinoma $[131,133,214,215]$. The most common oncolytic viruses that have been used for the treatment of cancer in clinical trials are adenovirus, HSV-1, reovirus, and poxviruses. The majority of studies used GM-CSG as a transgene for oncolytic viruses to enhance the recruitment and maturation of dendritic cells and, finally, to generate immune responses by promoting the cross-presentation of tumor antigens [216-219].

Phage nanobioparticles (NBPs). Phage display is a nanotechnology with potential and without any described limitations that was first developed in 1985. In 2018, the procedure for isolating high-affinity ligands for diverse substrates, ranging from recombinant proteins to cells, organs, and even whole organisms, was awarded the Nobel Prize in Chemistry. Its application in cancer immunotherapy involves three main types of phage-display procedures: (1) phage display-derived peptides that mimic cancer antigens (mimotopes), (2) antigen-carrying phage particles as prophylactic and/or therapeutic vaccines, and (3) phage display-derived peptides as small-molecule effectors of immune cell functions [220]. Some peptides displayed by phages can be used as modulators of immune system cells, stimulating effector cells (lymphocytes and APC) or inhibiting suppressor cells (Tregs and TAMs). The advantages of phages as carriers derive from their immunogenicity in association with low toxicity [221]. This technology has some limitations related to peptide stability and delivery, phage immunogenicity, and the challenges related to the diversity of human immunogenetics [222]. The technology of mimotopes of tumor-associated antigens (TAAs) that stimulate the production of anti-TAA Abs was developed, and these can be administered as full-length TAAs, partial proteins comprising only the antigenic parts, or TAA mimotopes (mimotopes of CD20, HER2, and EGFR). This type of cancer vaccination involves the presentation of a TAA or mimotope to the immune system of a patient to stimulate an immune response. Using mimotopes, this response may be focused against a peptide or against a peptide genetically or chemically anchored to the phage 
surface. It was demonstrated that the aggregation of a peptide with a phage particle results in a better response and a lower immunogenicity in comparison to the use of another carrier, e.g., ovalbumin (OVA) [222]. Another application of phage display is carrying derived peptides as nanomodulators of the immune response. One of the procedures of phage display involves the indirect targeting of the immune system. Phage display-derived peptides functioning as nanomodulators of the immune response with two main applications have been described, namely, in interfering with the activity of immune cells or with immune checkpoints.

\section{Potential Targets for Nanomedicine-Based Cancer Immunotherapy}

The aims for using nanovectors in cancer are to improve the delivery of therapeutic drugs to tumors and metastases and to modulate the immune system, for which three principal targets exist and represent directions for further exploration: cancer cells, the tumor immune microenvironment (TIME), and the peripheral immune system. Various types of inorganic nanoparticles have been designed for targeting cancer cells, the TIME, and the peripheral immune system, including PLGA, liposomes, hafnium oxide NPs, gold NPs, micelles, mesoporous silica, and carbon nanotubes. Current cancer immunotherapies are often based on the use of ACT, therapeutic cancer vaccines, and monoclonal antibodies.

\subsection{Cancer Cells as a Target for NP-Based Immunotherapy}

Nanovectors can be used to enhance the induction of immunogenic cell death (ICD). ICD can be induced by chemotherapeutics (e.g., doxorubicin, oxaliplatin, and cyclophosphamide) or radiotherapy, magnetic fluid hyperthermia, photodynamic therapy, or other stimuli [223]. So-called "in situ tumor vaccines" are nanoparticles designed for ICD that provide a new way to promote more efficient immunotherapy through combination with ICDinducing modalities. ICD is characterized by the release of TAAs and danger-associated molecular patterns (DMAPs). ICD is characterized by the translocation of calreticulin (CRT) to the cell surface and release of ATP and the high mobility group box 1 protein (HMGB1) into the extracellular environment. These modifications alert the immune system, which activates APC and cytotoxic T cells that eradicate tumors and metastases. Doxorubicin-loaded liposomes (Caelyx/Doxil) can increase the efficacy of immunotherapy when combined [224]. It is supposed that Doxil, through ICD, promotes the proliferation of DCs and CD8 ${ }^{+} \mathrm{T}$ cells. It was demonstrated that the immunopotentiation for Doxil is higher than that for doxorubicine administered at the same dose. Similar results were reported for oxaliplatin-loaded PLGA nanoparticles, which induce ICD and are more efficient in activating the immune system than free oxaliplatin [225].

For tumor-targeted delivery, immunotherapeutic agents were also used in combined photodynamic therapy-radiotherapy. It was demonstrated that pyrolipid-loaded inorganic nanoparticles enhance immunoactivation and ICD induction in photodynamic therapy when combined with anti-PD-L1. This ICD induction increases the serum levels of proinflammatory cytokines, such as TNF- $\alpha$, IL-6, and IFN- $\gamma$, while also improving the tumor infiltration of $\mathrm{CD}^{+}$and $\mathrm{CD}^{+}$cells, eradicating the primary tumor, and preventing lung metastasis through an abscopal effect [226]. The abscopal effect represents a phenomenon whereby local radiotherapy induces a systemic immune response and the regression of metastatic lesions [227]. Blocking TGF- $\beta$ activity during radiation therapy was observed to generate $\mathrm{CD}^{+} \mathrm{T}$ cell responses to endogenous tumor antigens. The addition of antiPD-1 and/or anti-CD137 antibodies resulted in a prolongation of survival achieved with radiation in combination with the TGF- $\beta$ blockade [228-231]. Nanomedicines inducing ICD result in improved antitumor immunity through decreased systemic lymphocyte toxicity, which also potentiates immunotherapy outcomes [232]. Moreover, locally injected nanoparticles are able to induce systemic immunity via an abscopal effect [233]. The European Medicines Agency approved intratumoral injections of NBTXR3 hafnium oxide nanoparticles designed to enhance the radiation-induced abscopal effect of radiotherapy for patients with locally advanced soft-tissue sarcomas [234]. 


\subsection{Tumor Immune Microenvironment (TIME) as a Target for NP-Based Immunotherapy}

Immunosuppressive mediators and pathways are upregulated in the TIME by an increase in the infiltration of immunosuppressive cells, such as tumor-associated macrophages (TAMs) and MDSCs, into tumors and enhancement of the levels of inhibitors, such as IDO and TGF- $\beta$.

Moreover, tumor acidity and hypoxia are the two main conditions that can be targeted to modify the immune response. It has been demonstrated that hypoxia has a negative regulatory effect on T cell activation, enhancing the expression of CCL22 and CCL28 and resulting in MDSC and Treg accumulation [235].

Hypoxia increases the secretion of immunosuppressive factors (VEGF and TGF- $\beta$ ) in addition to the expression of PDL-1 on the T cell immunoglobulin domain, mucin domain3 (TIM-3), and CTLA4 on MDSCs, TAMs, and Tregs [236]. $\mathrm{pH} / \mathrm{H}_{2} \mathrm{O}_{2}$ dual-responsive nanoparticles were designed using albumin-coated $\mathrm{MnO}_{2}$. Upon tumor penetration, $\mathrm{MnO}_{2}$ reacted with $\mathrm{H}_{2} \mathrm{O}_{2}$ and $\mathrm{H}^{+}$to produce oxygen, enhancing the therapeutic effects of chemotherapy and photodynamic therapy [237]. Another immunoliposome was developed, known as CAT@aPDL1-SSL, which represents another immunoliposome developed that contains catalase (CAT)-encapsulated liposomes and a modified PDL-1 for improving immunotherapeutic effects, enhancing T cells in tumor tissues, and blocking the PD-1/PDL1 pathway. The liposomes decrease hypoxia through the decomposition of endogenous $\mathrm{H}_{2} \mathrm{O}$ into $\mathrm{O}_{2}$ [238]. The extracellular $\mathrm{pH}$ of most tumor tissues is found to be lower than that of normal tissues [239]. The mild acidic tumor microenvironment is the consequence of the high glycolysis rate of tumor cells, with lactic acid accumulation.

pH-responsive PCL-Hyd-PEG nanovesicles that encapsulate immunological adjuvants (CpG ODNs) and endogenous tumor antigens as heat shock protein 70-chaperoned polypeptides (HCP) were constructed to enhance cancer immunotherapy. These nanovesicles are fragmented in the acidic tumor microenvironment and release the encapsulated drugs [240]. Furthermore, $\mathrm{pH}$-responsive size-switchable or dissociable nanoparticles were developed. It was demonstrated that nanoparticles with smaller diameters efficiently expanded into the tumor, and N-(2-hydroxypropyl) methacrylamide (HPMA) polymer-based nanovehicles with a small size and ability to change the $\mathrm{pH}$ were developed for the delivery of chemotherapeutic drugs to the nucleus [241].

Dendritic cells (DCs) as a target for NP-based immunotherapy. Dendritic cells (DCs) are multifunctional regulators of immunity.

It has been well demonstrated a cross-presentation process of antigens endocytosed by DCs to $\mathrm{CD} 8^{+}$cytotoxic cells [242]. Tumor-associated antigens and adjuvants targeting the dendritic cells and tumor-specific $\mathrm{T}$ cells were used as therapeutic cancer vaccines and positive results were reported in preclinical and clinical experiments involving immunotherapy with manipulated DCs [243]. Sipuleucel-T was the first DC-based vaccine approved by FDA for patients with hormone-resistant advanced prostate cancer. Other strategies targeting DCs have been experimented in vivo [244]. The selective uptake of DCs and the decreasing of off-target drug interactions have been also studied [245-247].

One application of DC targeting by nanomedicines is in RNA modulation. In a study on specific delivery systems, siRNA carried by liposomes was targeted to DCs for silencing CD40 expression in vitro [248].

In the clinical testing of vaccines, low-immunogenicity lipid-based RNA nanoparticles were designed for the delivery of mRNA into DCs. These widely used cationic lipid materials (DOTMA, DOTAP, and DOPE) and anionic mRNA form RNA lipoplexes that ensure efficient and precise DC-targeted mRNA delivery without the need for molecular ligands, such as antibodies [249]. Nanoparticle-mediated hyperthermia activates DCs, and combination therapy with magnetic nanoparticle-induced hyperthermia, radiotherapy, and a virus-like particle adjuvant was demonstrated to be effective in the treatment of dogs with oral melanoma [250].

Tumor-associated macrophages (TAMs) as a target for NP-based immunotherapy. TAMs are immune cells with an M2-like phenotype in tumors with pro-tumoral functions 
in suppressing the infiltration of effector T cells [251,252]. It was demonstrated that ferumoxytol changed M2-like TAMs into M1-like TAMs and inhibited the growth of primary and metastatic tumors in the liver and lungs [253]. In another study, it was found that cyclodextrin nanoparticles are targeting a small-molecule Toll-like receptor $7 / 8$ agonist that binds TLR7/8 intracellular receptors expressed on the endosomal membranes of macrophages in the TIME, resulting in the induction of M2-to-M1 polarization, enhancing the efficacy of checkpoint inhibitors [254].

The increase in macrophages polarized toward an M1 phenotype is followed by improved outcomes of checkpoint-blockade therapy when using $\mathrm{CaCO}_{3}$ nanoparticles functionalized with anti-CD47 antibodies [255]. Two immunosuppressive molecules from the TIME-IDO and TGF- $\beta$ - were also targeted by the nanoparticles.

Indoleamine 2,3-dioxygenase (IDO) as a target for NP-based immunotherapy. The role of IDO is to enhance the production of kynurenine, a T cell-suppressing metabolite. Molecules of IDO inhibitors incorporated into nanomedicine formulations were tested in preclinical and clinical trials, and synergic mechanisms between IDO inhibitor-loaded nanomedicines and photodynamic therapy and radiotherapy were observed [256]. An IDO inhibitor was combined with oxaliplatin to enhance ICD in lipid-coated mesoporous silica nanoparticles, followed by tumor reduction in pancreatic ductal adenocarcinoma [257]. Another IDO inhibitor was used together with a peptide that blocked PD-L1 in peptidebased nanoparticles, which effectively inhibited melanoma growth in mice by stimulating anticancer immunity [258].

TGF- $\beta$ as a target for NP-based immunotherapy. TGF- $\beta$ was found to inhibit the efficacy of checkpoint inhibitors $[259,260]$. A TGF- $\beta$ inhibitor encapsulated in PEGylated immune liposomes was demonstrated to increase the $\mathrm{T}$ cell triggering of the receptors CD90 and CD45 [261]. TGF- $\beta$-siRNA-containing nanoparticles were developed, which were shown to downregulate TGF- $\beta$ expression in tumors [262].

\subsection{Peripheral Immune System as a Target for NP-Based Immunotherapy}

The peripheral immune system, defined as immune compartments located outside tumors, is mainly composed of secondary lymphoid organs, which are the places where antigen presentation and cytotoxic- $T$ cell generation occur. These compartments are frequently impaired in cancer progression. The functions of the peripheral immune system can be restored by the potentiation of antigen presentation and by engineering $\mathrm{T}$ cells. The subcutaneous or intradermal administration of antigen-containing nanoparticles results in more efficient processing by APCs [263]. CpG conjugated with nanoparticles or loaded together with peptide antigens in nanodiscs was administered in local injections targeting lymph nodes for promoting anticancer immunity [264,265]. In addition, the Toll-like receptor $7 / 8$ agonist imidazoquinoline entrapped in nanogels or CpG bound with albumin was injected locally or systemically with the intention of it reaching the lymph nodes. Such vaccines demonstrate the tolerability of adjuvants [266].

Another antitumor vaccine was developed using PLGA nanoparticles containing antigens, which were administered to target lymph nodes for the delivery of antigens to DCs, resulting in significantly improved immunotherapy and an ex vivo abscopal effect in tumor-bearing mice receiving $\alpha$ PD-1 immunotherapy treatment $[267,268]$. A nanovaccine was designed based on the combination of an antigen and a synthetic polymeric nanoparticle, PC7A-NP, which, after administration, delivered antigens to antigen-presenting cells from lymph nodes, activating type I interferons. This vaccine, in combination with the anti-PD-1 antibody, resulted in 100\% survival over 60 days when applied in a tumor model [269]. Another strategy involves generating cytotoxic T cells to replace APCs. Synthetic APCs were designed based on a polypeptide modified with anti-CD3 antibodies included in the polymer chain, which enhanced the expression of CD69 [270]. Synthetic biometric magnetosomes were also prepared as versatile artificial APCs that trigger cytotoxic T cells, and they promote tumor inhibition when administered together with T cells in tumors [271]. Liposomes loaded with IL-15 and IL-21 or cytokine-based nanogels mod- 
ulating the release of IL-15 were also studied [272]. An antigen-encoding mRNA within a lipoplex has already been studied in clinical trials, as a monotherapy or combined with immunotherapeutics [273].

\section{A Possible Mathematical Model for Cellular Communication Mechanisms}

All cells in multicellular beings have the distinct requirement of communication with other cells for coordinating development and for adaptation and functional evolution. This communication involves many types of soluble factors in addition to specific recognition through cell-surface receptors. There is recent evidence that cells communicate directly via RNA exchange. When eukaryotic cells encounter double-stranded RNA (dsRNA), genes carrying a matching sequence can be silenced through RNA interference (RNAi).

However, the novelty is that, in some animals and plants, transporting a silencing signal between cells will allow the same gene to be specifically silenced in cells that had not encountered the primary dsRNA. This process can be seen in plants and C. elegans. In plants, silencing RNAs move from cell to cell through the plasmodesmata (PD), and over long distances through the phloem vascular tissue. When a leaf is, in general, infected with a virus, such mobile signals transmitted to others provide resistance to infection spread. Even if it was known for years that transgenes and viral-induced siRNAs move through the plant, the movement of endogenous small RNAs (sRNAs) has only recently been demonstrated.

The movement of endogenous small RNAs, which includes microRNAs (miRNAs), leads to signal gradients that may guide the patterning of leaves and roots. Such mobile sRNAs can promote epigenetic modifications in the genomes of recipient cells. Furthermore, if such recipient cells are pollen or seed-mobile, the sRNAs can induce transgenerational epigenetic changes, which enhance progeny adaptation to future stresses. In C. elegans, silencing initiated by dsRNA spreads through the organism, which silences the targeted gene in all non-neuronal cells, including the germline, thus transmitting this silencing to the next generation.

Intercellular communication has been extensively studied, since it helps to directly transfer information between cells or through various molecules created by them. Extracellular vesicle $(\mathrm{EV})$ secretion is a common process that has been identified in many biological fluids. EVs facilitate the exchange of nucleic acids, lipids, and proteins between cells, playing an important role in cell signaling [274].

Cell communication in the human body and, especially, in cell microenvironments plays an essential role in cancer development and tumor growth [275]. Exosomes are a class of EVs secreted by all types of cells that are involved in intracellular communication with other nearby or distant cells, immunological actions, cancer metastasis, or other organ-specific processes [276]. They are composed of a phospholipid double layer and are between 50 and $100 \mathrm{~nm}$ in diameter [277]. They are important in all components of a cell, even in the case of DNA, miRNA, mRNA, or proteins. Although exosomes were first described 50 years ago, their role in the development of cancer as potential "biomarkers" has been extensively researched over the past decade [278].

The classical models used in these studies are usually based on the unjustified assumption that the variables describing the dynamics of any cell complex are differentiable [279]. Therefore, the success of these models must be understood as sequential, existing only in areas where differentiability and integrability are valid. These procedures are not appropriate when the dynamics of a cell complex involve nonlinearity (chaoticity and self-structuring).

However, the notion of scale resolution for variable expression must be introduced to describe these dynamics using differential and non-differential procedures, especially in the expression of fundamental equations that control such dynamics. Thus, any variable that depends on spatio-temporal coordinates will depend on space and time, yet also scale resolutions in the new mathematical sense, which is that of non-differentiability and non-integrability. 
The functionality of a variable described by non-differentiable functions is replaced with approximations of this function obtained through averaging at various scale resolutions. Resulting from these procedures, any and all variables developed in order to describe complex cellular dynamics can be a limit of function families that are nondifferentiable for a zero-scale resolution and differentiable for non-zero-scale resolutions [280,281].

The method of describing the dynamics of any complex cellular system involves the development of new geometric structures in addition to new mathematical models. For these, the laws of motion, invariant to spatial and temporal transformations, are integrated with scaling laws, which are also invariant. According to the authors, such a structure can be based on the concept of multifractality, and the corresponding model can be based on the fractal theory of motion in an arbitrary and constant fractal dimension. For complex biological systems, the dynamics analysis is similar to the one given in [282].

The fundamental assumption of the model is that the dynamics of the structural units of any complex cellular system will be described by continuous and nondifferentiable curves (motion multifractality curves). They have properties of self-similarity at each point, which can be translated as properties of holography (where each part reflects the whole). Basically, the discussion revolves around "holographic implementations of the structural unit dynamics of any cellular complex system" through multifractal "regimes" [282].

This implementation naturally implies many types of operational procedures (invariance groups, harmonic mappings, groups isomorphism, embedding manifolds, etc.) with many applications in complex systems dynamics, such as the matter of explaining the dynamics of a cellular system. It is thus possible to observe and quantify nonlinear behaviors at a global scale resolution, nondissipative nonlinear behaviors at a differentiable scale resolution, and even dissipative nonlinear behaviors at a nondifferentiable scale resolution. Finally, whatever the type and exact measure of the scale resolution, such cellular dynamics can be reduced to self-structuring cellular patterns that, through the phasing and dephasing of the positive and negative parts of their respective complex potential fields, can dictate where and how EV secretion can take place.

\section{Discussion}

Nanopharmaceuticals and bioinspired nanovectors (nanobioparticles) remain the two main categories of nanovectors involved in the modulation of cancer immunotherapy. However, great efforts are still required to facilitate further understanding of the in vivo fate of nanopharmaceuticals.

A new research strategy for influencing immunotherapy is that represented by 2D nanomaterials. Two-dimensional (2D) nanomaterials differ from their conventional zerodimensional (0D) and one-dimensional counterparts in showing unique properties that result from their specific structure and morphology. Two-dimensional-based drug-delivery systems show great potential and represent a novel direction for the expansion of innovative biomedical applications.

Biointeractions between the immune system and nanomaterials, including 2D nanomaterials, affect the immune system, and it is essential to identify all the factors related to biological safety.

The complexity and heterogeneity of the immune-nanomaterial interface still represent an issue in developing nanopharmaceuticals. Different interactions between nanomaterials (NMs) and immune cell membranes result in different immune responses. The immunenanomaterial interface is represented by specific characteristics, such as stereoselective interaction, hydrophobicity, electrostatic interaction, hydrogen bonding, metal coordination, and molecular recognition, which cause structural remodeling and the dysfunction of nanomaterials. Consequently, the surface properties, biological functions, intracellularuptake pathways, and fate of nanomaterials are affected [283].

The existence of entropic and nanothermodynamic potentials at immune-nanomaterial interfaces have also been described, regulating the receptors on macrophage surfaces and stimulating the secretion of cytokines [284]. 
At present, there is a sustained effort toward developing comprehensive databases, for example, protein corona fingerprints and a biological response database of various types of NMs and a nanocombinatorial library strategy [285,286].

The development of databases for nanomaterial-related immunity is still in its infancy, but these databases can predict biological responses and the basic mechanisms of nanoimmune interactions, and allow screening for safe and effective NMs. Moreover, the combination of multivariate immune analysis, data integration, and machine learning can provide insight into the impact of the immune responses induced by nanomaterials $[287,288]$.

Another route in the development of nanovectors is represented by bioinspired vectors, with major potential for development in the coming decades. New strategies to improve oncolytic virotherapy in the future have been described.

A strategy based on the use of a protective coating to physically shield OVs to prevent the action of soluble immune factors was developed, involving the use of liposomes, polymers, and cell-derived nanovesicles [289]. Cellular carriers derived from T cells, endothelial cells, mesenchymal stromal cells, and also from adipose-derived stem cells were designed to deliver viruses, such as vaccinia virus and vesicular stomatitis virus [290,291]. Some epitopes on OVs were also identified and genetically modified, preventing the premature exposure of pre-existing antibodies [292,293].

\section{Conclusions}

Future directions involving nanomedicine to modulate immunotherapy in cancer treatment are needed to increase the effectiveness of treatments. The major issues in nanotechnology-based immunotherapy are represented by the optimization of tumor targeting, the control of toxicity, and drug delivery versus clearance.

Additionally, complementing classic checkpoint inhibitors is the promising discovery of new checkpoint co-stimulators, such as OX40/OX40L, which promotes the survival and proliferation of CD4 and CD8 T cells; GITR/GITRL, which exerts a regulatory function on Tregs; and 4-1BB/4-1BBL, which has a co-stimulatory effect on different immune cells (T cells, NK cells, Tregs, and NK T cells). Checkpoint inhibitors, such as LAG-3, TIGIT, VISTA, and TIM-3, or enhancers of cellular immunity (STING agonists, IDO/TDO, and TRL agonists) are also of interest.

The major direction for developing nanovector technologies to enhance immunotherapy appears to involve nanopharmaceuticals, bioinspired nanoparticles, and combinations of them, which have great potential to be demonstrated in the coming decades.

Author Contributions: Conceptualization, S.-R.V., C.L.U. and L.G.M.; methodology, C.V.; writingoriginal draft preparation, S.-R.V., C.L.U., L.G.M., D.B., F.A., C.S., C.R.S., C.L., D.S. and C.C.V.; writing-review and editing, D.S., M.A. and C.V. All authors have read and agreed to the published version of the manuscript.

Funding: This research received no external funding.

Institutional Review Board Statement: Not Applicable.

Informed Consent Statement: Not Applicable.

Data Availability Statement: All data are presented in the manuscript.

Conflicts of Interest: The authors declare no conflict of interest.

\section{References}

1. Stoler, D.L.; Chen, N.; Basik, M.; Kahlenberg, M.S.; Rodriguez-Bigas, M.A.; Petrelli, N.J.; Anderson, G.R. The onset and extent of genomic instability in sporadic colorectal tumor progression. Proc. Natl. Acad. Sci. USA 1999, 96, 15121-15126. [CrossRef] [PubMed]

2. Leach, D.R.; Krummel, M.F.; Allison, J.P. Enhancement of Antitumor Immunity by CTLA-4 Blockade. Science 1996, 271, 1734-1736. [CrossRef] [PubMed] 
3. Dong, H.; Strome, S.E.; Salomao, D.R.; Tamura, H.; Hirano, F.; Flies, D.B.; Roche, P.C.; Lu, J.; Zhu, G.; Tamada, K.; et al. Tumorassociated B7-H1 promotes T-cell apoptosis: A potential mechanism of immune evasion. Nat. Med. 2002, 8, 793-800. [CrossRef] [PubMed]

4. Iwai, Y.; Ishida, M.; Tanaka, Y.; Okazaki, T.; Honjo, T.; Minato, N. Involvement of PD-L1 on tumor cells in the escape from host immune system and tumor immunotherapy by PD-L1 blockade. Proc. Natl. Acad. Sci. USA 2002, 99, 12293-12297. [CrossRef] [PubMed]

5. Blank, C.; Brown, I.; Peterson, A.C.; Spitto, M.; Iwai, Y.; Honjo, T.; Gajewki, T.F. PD-L1/B7H-1 inhibits the effector phase of tumor rejection by $\mathrm{T}$ cell receptor (TCR) transgenic CD8 ${ }^{+} \mathrm{T}$ cells. Cancer Res. 2004, 64, 1140-1145. [CrossRef] [PubMed]

6. Zou, W.; Wolchok, J.D.; Chen, L. PD-L1 (B7-H1) and PD-1 pathway blockade for cancer therapy: Mechanisms, response biomarkers, and combinations. Sci. Transl. Med. 2016, 8, 328rv4. [CrossRef] [PubMed]

7. Vesely, M.D.; Kershaw, M.H.; Schreiber, R.D.; Smyth, M.J. Natural Innate and Adaptive Immunity to Cancer. Annu. Rev. Immunol. 2011, 29, 235-271. [CrossRef]

8. Chen, D.S.; Mellman, I. Elements of cancer immunity and the cancer-immune set point. Nature 2017, 541, 321-330. [CrossRef]

9. Chen, I.X.; Chauhan, V.; Posada, J.; Ng, M.R.; Wu, M.; Adstamongkonkul, P.; Huang, P.; Lindeman, N.; Langer, R.; Jain, R.K. Blocking CXCR4 alleviates desmoplasia, increases T-lymphocyte infiltration, and improves immunotherapy in metastatic breast cancer. Proc. Natl. Acad. Sci. USA 2019, 116, 4558-4566. [CrossRef]

10. Chauhan, V.; Chen, I.X.; Tong, R.; Ng, M.R.; Martin, J.D.; Naxerova, K.; Wu, M.; Huang, P.; Boucher, Y.; Kohane, D.S.; et al. Reprogramming the microenvironment with tumor-selective angiotensin blockers enhances cancer immunotherapy. Proc. Natl. Acad. Sci. USA 2019, 116, 10674-10680. [CrossRef]

11. Ebert, P.J.; Cheung, J.; Yang, Y.; McNamara, E.; Hong, R.; Moskalenko, M.; Gould, S.E.; Maecker, H.; Irving, B.A.; Kim, J.M.; et al MAP Kinase Inhibition Promotes T Cell and Anti-tumor Activity in Combination with PD-L1 Checkpoint Blockade. Immunity 2016, 44, 609-621. [CrossRef] [PubMed]

12. Mariathasan, S.; Turley, S.J.; Nickles, D.; Castiglioni, A.; Yuen, K.; Wang, Y.; Kadel, E.E., III; Koeppen, H.; Astarita, J.L.; Cubas, R.; et al. TGF $\beta$ attenuates tumour response to PD-L1 blockade by contributing to exclusion of T cells. Nature 2018, 554, 544-548. [CrossRef] [PubMed]

13. Galon, J.; Bruni, D. Approaches to treat immune hot, altered and cold tumours with combination immunotherapies. Nat. Rev. Drug Discov. 2019, 18, 197-218. [CrossRef]

14. Mlecnik, B.; Tosolini, M.; Kirilovsky, A.; Berger, A.; Bindea, G.; Meatchi, T.; Bruneval, P.; Trajanoski, Z.; Fridman, W.-H.; Pagès, F.; et al. Histopathologic-Based Prognostic Factors of Colorectal Cancers Are Associated with the State of the Local Immune Reaction. J. Clin. Oncol. 2011, 29, 610-618. [CrossRef]

15. Galon, J.; Angell, H.K.; Bedognetti, D.; Marincola, F.M. The Continuum of Cancer Immunosurveillance: Prognostic, Predictive, and Mechanistic Signatures. Immunity 2013, 39, 11-26. [CrossRef] [PubMed]

16. Angell, H.; Galon, J. From the immune contexture to the Immunoscore: The role of prognostic and predictive immune markers in cancer. Curr. Opin. Immunol. 2013, 25, 261-267. [CrossRef]

17. Galluzzi, L.; Senovilla, L.; Vacchelli, E.; Eggermont, A.; Fridman, W.H.; Galon, J.; Sautès-Fridman, C.; Tartour, E.; Zitvogel, L.; Kroemer, G. Trial watch. OncoImmunology 2012, 1, 1111-1134. [CrossRef]

18. Galon, J.; Mlecnik, B.; Bindea, G.; Angell, H.K.; Berger, A.; Lagorace, C.; Lugli, A.; Zlobec, I.; Hartmann, A.; Bifulco, C.; et al. Towards the introduction of the 'Immunoscore' in the classification of malignant tumours. J. Pathol. 2014, 232, 199-209. [CrossRef]

19. Mellman, I.; Coukos, G.; Dranoff, G. Cancer immunotherapy comes of age. Nature 2011, 480, 480-489. [CrossRef] [PubMed]

20. Oiseth, S.J.; Aziz, M.S. Cancer immunotherapy: A brief review of the history, possibilities, and challenges ahead. J. Cancer Metastasis Treat. 2017, 3, 250. [CrossRef]

21. Sharma, P.; Wagner, K.; Wolchok, J.D.; Allison, J.P. Novel cancer immunotherapy agents with survival benefit: Recent successes and next steps. Nat. Cancer 2011, 11, 805-812. [CrossRef] [PubMed]

22. Van den Bulk, J.; Verdegaal, E.M.; de Miranda, N.F. Cancer immunotherapy: Broadening the scope of targetable tumours. Open Biol. 2018, 8, 180037. [CrossRef] [PubMed]

23. Majzner, R.G.; Heitzeneder, S.; Mackall, C.L. Harnessing the Immunotherapy Revolution for the Treatment of Childhood Cancers. Cancer Cell 2017, 31, 476-485. [CrossRef] [PubMed]

24. Fried, I.; Lossos, A.; Ben Ami, T.; Dvir, R.; Toledano, H.; Ben Arush, M.W.; Postovski, S.; Abu Kuidar, A.; Yalon, M.; Weintraub, M.; et al. Preliminary results of immune modulating antibody MDV9300 (pidilizumab) treatment in children with diffuse intrinsic pontine glioma. J. Neuro-Oncol. 2017, 136, 189-195. [CrossRef]

25. Ishizuka, J.J.; Manguso, R.T.; Cheruiyot, C.K.; Bi, K.; Panda, A.; Iracheta-Vellve, A.; Miller, B.; Du, P.; Yates, K.B.; Dubrot, J.; et al. Loss of ADAR1 in tumours overcomes resistance to immune checkpoint blockade. Nature 2018, 565, 43-48. [CrossRef]

26. Tykodi, S.S.; Brahmer, J.R.; Hwu, W.-J.; Chow, L.Q.; Topalian, S.L.; Odunsi, P.H.; Camacho, L.H.; Kauh, J.S.; Pitot, H.C.; Hamid, O.; et al. PD-1/PD-L1 pathway as a target for cancer immunotherapy: Safety and clinical activity of BMS-936559, an anti-PD-L1 antibody, in patients with solid tumors. J. Clin. Oncol. 2012, 30, 2510. [CrossRef]

27. Tang, B.; Yan, X.; Sheng, X.; Si, L.; Cui, C.; Kong, Y.; Mao, L.; Lian, B.; Bai, X.; Wang, X.; et al. Safety and clinical activity with an anti-PD-1 antibody JS001 in advanced melanoma or urologic cancer patients. J. Hematol. Oncol. 2019, 12, 7. [CrossRef]

28. Sambi, M.; Bagheri, L.; Szewczuk, M.R. Current Challenges in Cancer Immunotherapy: Multimodal Approaches to Improve Efficacy and Patient Response Rates. J. Oncol. 2019, 2019, 1-12. [CrossRef] 
29. Sharma, P.; Hu-Lieskovan, S.; Wargo, J.A.; Ribas, A. Primary, Adaptive, and Acquired Resistance to Cancer Immunotherapy. Cell 2017, 168, 707-723. [CrossRef]

30. Kato, S.; Goodman, A.; Walavalkar, V.; Barkauskas, D.A.; Sharabi, A.; Kurzrock, R. Hyperprogressors after Immunotherapy: Analysis of Genomic Alterations Associated with Accelerated Growth Rate. Clin. Cancer Res. 2017, 23, 4242-4250. [CrossRef]

31. Champiat, S.; Dercle, L.; Ammari, S.; Massard, C.; Hollebecque, A.; Postel-Vinay, S.; Chaput, N.; Eggermont, A.M.; Marabelle, A.; Soria, J.-C.; et al. Hyperprogressive Disease Is a New Pattern of Progression in Cancer Patients Treated by Anti-PD-1/PD-L1. Clin. Cancer Res. 2017, 23, 1920-1928. [CrossRef] [PubMed]

32. Kato, S.; Ross, J.S.; Gay, L.; Dayyani, F.; Roszik, J.; Subbiah, V.; Kurzrock, R. Analysis of MDM2 Amplification: Next-Generation Sequencing of Patients with Diverse Malignancies. JCO Precis. Oncol. 2018, 2, 1-14. [CrossRef] [PubMed]

33. Lo Russo, G.; Moro, M.; Sommariva, M.; Cancila, V.; Boeri, M.; Centonze, G.; Ferro, S.; Ganzinelli, M.; Gasparini, P.; Huber, V.; et al. Antibody-Fc/FcR Interaction on Macrophages as a Mechanism for Hyperprogressive Disease in Non-small Cell Lung Cancer Subsequent to PD-1/PD-L1 Blockade. Clin. Cancer Res. 2019, 25, 989-999. [CrossRef] [PubMed]

34. Van Allen, E.M.; Miao, D.; Schilling, B.; Shukla, S.A.; Blank, C.; Zimmer, L.; Sucker, A.; Hillen, U.; Foppen, M.H.G.; Goldinger, S.M.; et al. Genomic correlates of response to CTLA-4 blockade in metastatic melanoma. Science 2015, 350, $207-211$. [CrossRef] [PubMed]

35. Savas, P.; Salgado, R.; Denkert, C.; Sotiriou, C.; Darcy, P.K.; Smyth, M.J.; Loi, S. Clinical relevance of host immunity in breast cancer: From TILs to the clinic. Nat. Rev. Clin. Oncol. 2016, 13, 228-241. [CrossRef]

36. Xing, X.; Guo, J.; Ding, G.; Li, B.; Dong, B.; Feng, Q.; Li, S.; Zhang, J.; Ying, X.; Cheng, X.; et al. Analysis of PD1, PDL1, PDL2 expression and T cells infiltration in 1014 gastric cancer patients. OncoImmunology 2017, 7, e1356144. [CrossRef]

37. Schalper, K.A.; Brown, J.; Carvajal-Hausdorf, D.; McLaughlin, J.; Velcheti, V.; Syrigos, K.N.; Herbst, R.S.; Rimm, D.L. Objective measurement and clinical significance of TILs in non-small cell lung cancer. J. Natl. Cancer Inst. 2015, 107, dju435. [CrossRef]

38. Shevtsov, M.; Sato, H.; Multhoff, G.; Shibata, A. Novel Approaches to Improve the Efficacy of Immuno-Radiotherapy. Front. Oncol. 2019, 9, 156. [CrossRef]

39. Galon, J.; Costes, A.; Sanchez-Cabo, F.; Kirilovsky, A.; Mlecnik, B.; Lagorce-Pagès, C.; Tosolini, M.; Camus, M.; Berger, A.; Wind, P.; et al. Type, density, and location of immune cells within human colorectal tumors predict clinical outcome. Science 2006, 313, 1960-1964. [CrossRef]

40. Paijens, S.T.; Vledder, A.; de Bruyn, M.; Nijman, H.W. Tumor-infiltrating lymphocytes in the immunotherapy era. Cell Mol. Immunol. 2021, 18, 842-859. [CrossRef]

41. Cabrita, R.; Lauss, M.; Sanna, A.; Donia, M.; Skaarup Larsen, M.; Mitra, S.; Johansson, I.; Phung, B.; Harbst, K.; Vallon-Christersson, J.; et al. Tertiary lymphoid structures improve immunotherapy and survival in melanoma. Nature 2020, 577, 561-565. [CrossRef] [PubMed]

42. Park, Y.-M.; Lee, S.J.; Kim, Y.S.; Lee, M.H.; Cha, G.S.; Jung, I.D.; Kang, T.H.; Han, H.D. Nanoparticle-Based Vaccine Delivery for Cancer Immunotherapy. Immune Netw. 2013, 13, 177-183. [CrossRef] [PubMed]

43. Agarwal, R.; Jurney, P.; Raythatha, M.; Singh, V.; Sreenivasan, S.V.; Shi, L.; Roy, K. Effect of Shape, Size, and Aspect Ratio on Nanoparticle Penetration and Distribution inside Solid Tissues Using 3D Spheroid Models. Adv. Health Mater. 2015, 4, 2269-2280. [CrossRef] [PubMed]

44. Toy, R.; Peiris, P.M.; Ghaghada, K.B.; Karathanasis, E. Shaping cancer nanomedicine: The effect of particle shape on the in vivo journey of nanoparticles. Nanomedicine 2014, 9, 121-134. [CrossRef] [PubMed]

45. Chena, H.; Lia, P.; Yina, Y.; Caia, X.; Huanga, Z.; Chena, J.; Donga, L.; Zhangab, J. The promotion of type $1 \mathrm{~T}$ helper cell responses to cationic polymers in vivo via toll-like receptor-4 mediated IL-12 secretion. Biomaterials 2010, 31, 8172-8180. [CrossRef]

46. Kasturi, S.; Sachaphibulkij, K.; Roy, K. Covalent conjugation of polyethyleneimine on biodegradable microparticles for delivery of plasmid DNA vaccines. Biomaterials 2005, 26, 6375-6385. [CrossRef]

47. Akhter, A.; Hayashi, Y.; Sakurai, Y.; Ohga, N.; Hida, K.; Harashima, H. Ligand density at the surface of a nanoparticle and different uptake mechanism: Two important factors for successful siRNA delivery to liver endothelial cells. Int. J. Pharm. 2014, 475, 227-237. [CrossRef]

48. Anselmo, A.C.; Zhang, M.; Kumar, S.; Vogus, D.R.; Menegatti, S.; Helgeson, M.E.; Mitragotri, S. Elasticity of Nanoparticles Influences Their Blood Circulation, Phagocytosis, Endocytosis, and Targeting. ACS Nano 2015, 9, 3169-3177. [CrossRef]

49. Toy, R.; Roy, K. Engineering nanoparticles to overcome barriers to immunotherapy. Bioeng. Transl. Med. 2016, 1, 47-62. [CrossRef]

50. Fischer, H.C.; Hauck, T.S.; Gómez-Aristizábal, A.; Chan, W.C.W. Exploring primary liver macrophages for studying quantum dot interactions with biological systems. Adv. Mater. 2010, 22, 2520-2524. [CrossRef]

51. Gordon, S.; Taylor, P. Monocyte and macrophage heterogeneity. Nat. Rev. Immunol. 2005, 5, 953-964. [CrossRef] [PubMed]

52. Syed, A.; Chan, W.C.W. How nanoparticles interact with cancer cells. Cancer Treat Res. 2015, 166, 227-244. [CrossRef] [PubMed]

53. Patel, P.C.; Giljohann, D.A.; Daniel, W.L.; Zheng, D.; Prigodich, A.E.; Mirkin, C.A. Scavenger Receptors Mediate Cellular Uptake of Polyvalent Oligonucleotide-Functionalized Gold Nanoparticles. Bioconj. Chem. 2010, 21, 2250-2256. [CrossRef] [PubMed]

54. Bae, Y.H.; Park, K. Targeted drug delivery to tumors: Myths, reality and possibility. J. Control. Release 2011, 153, 198-205. [CrossRef] [PubMed]

55. Jang, S.H.; Wientjes, M.G.; Lu, D.; Au, J.L. Drug delivery and transport to solid tumors. Pharm. Res. 2003, 20, 1337-1350. [CrossRef] 
56. Lazarovits, J.; Chen, Y.Y.; Sykes, E.A.; Chan, W.C.W. Nanoparticle-blood interactions: The implications on solid tumour targeting. Chem. Commun. 2014, 51, 2756-2767. [CrossRef]

57. Nichols, J.W.; Bae, Y.H. Odyssey of a cancer nanoparticle: From injection site to site of action. Nano Today 2012, 7, 606-618. [CrossRef]

58. Florence, A.T. "Targeting" nanoparticles: The constraints of physical laws and physical barriers. J. Control. Release 2012, 164, 115-124. [CrossRef]

59. Wilhelm, S.; Tavares, A.J.; Dai, Q.; Ohta, S.; Audet, J.; Dvorak, H.F.; Chan, W.C.W. Analysis of nanoparticle delivery to tumours Nat. Rev. Mater. 2016, 1, 16014. [CrossRef]

60. Maeda, H.; Nakamura, H.; Fang, J. The EPR effect for macromolecular drug delivery to solid tumors: Improvement of tumor uptake, lowering of systemic toxicity, and distinct tumor imaging in vivo. Adv. Drug Deliv. Rev. 2012, 65, 71-79. [CrossRef]

61. Huang, X.; Peng, X.; Wang, Y.; Wang, Y.; Shin, D.M.; El-Sayed, M.A.; Nie, S. A Reexamination of Active and Passive Tumor Targeting by Using Rod-Shaped Gold Nanocrystals and Covalently Conjugated Peptide Ligands. ACS Nano 2010, 4, 5887-5896. [CrossRef] [PubMed]

62. Schwartz, M.A.; Lund, A.W. Limphatic and interstitial flow in the tumor microenvironment: Linking mechanobiology with immunity. Nat. Rev. Cancer 2012, 12, 210. [CrossRef] [PubMed]

63. Yuan, F.; Salehi, A.H.; Boucher, Y.; Vasthare, U.S.; Tuma, R.F.; Jain, R.K. Vascular permeability and microcirculation of gliomas and mammary carcinomas transplanted in rat and mouse cranial windows. Cancer Res. 1994, 54, 4564-4568. [PubMed]

64. Schmidt, M.M.; Wittrup, K.D. A modeling analysis of the effects of molecular size and binding affinity on tumor targeting. Mol. Cancer Ther. 2009, 8, 2861-2871. [CrossRef] [PubMed]

65. Heldin, C.-H.; Rubin, K.; Pietras, K.; Östman, A. High interstitial fluid pressure-An obstacle in cancer therapy. Nat. Cancer 2004, 4, 806-813. [CrossRef]

66. Flessner, M.F.; Choi, J.; Credit, K.; Deverkadra, R.; Henderson, K. Resistance of Tumor Interstitial Pressure to the Penetration of Intraperitoneally Delivered Antibodies into Metastatic Ovarian Tumors. Clin. Cancer Res. 2005, 11, 3117-3125. [CrossRef]

67. Jain, R.K.; Stylianopoulos, T. Delivering nanomedicine to solid tumors. Nat. Rev. Clin. Oncol. 2010, 7, 653-664. [CrossRef]

68. Pedersen, J.A.; Boschetti, F.; Swartz, M.A. Effects of extracellular fiber architecture on cell membrane shear stress in a 3D fibrous matrix. J. Biomech. 2007, 40, 1484-1492. [CrossRef]

69. Fleischer, C.C.; Payne, C.K. Secondary structure of corona proteins determines the cell surface receptors used by nanoparticles. J. Phys. Chem. 2014, 118, 14017-14026. [CrossRef]

70. Barbero, F.; Russo, L.; Vitali, M.; Piella, J.; Salvo, I.; Borrajo, M.L.; Busquets-Fité, M.; Grandori, M.; Bastús, N.G.; Casals, E.; et al. Formation of the protein corona: The interface between nanoparticles and the immune system. Semin. Immunol. 2017, 34, 52-60. [CrossRef]

71. Shanehsazzadeh, S.; Gruettner, C.; Lahooti, A.; Mahmoudi, M.; Allen, B.J.; Ghavami, M.; Daha, F.J.; Oghabian, M.A. Mono-clonal antibody conjugated magnetic nanoparticles could target MUC-1-positive cells in vitro but not in vivo. Contrast Media Mol. Imaging 2015, 10, 225-236. [CrossRef] [PubMed]

72. Bargheer, D.; Nielsen, J.; Gébel, G.; Heine, M.; Salmen, S.C.; Stauber, R.; Weller, H.; Heeren, J.; Nielsen, P. The fate of a designed protein corona on nanoparticles in vitro and in vivo. Beilstein, J. Nanotechnol. 2015, 6, 36-46. [CrossRef] [PubMed]

73. Lartigue, L.; Wilhelm, C.; Servais, J.; Factor, C.; Dencausse, A.; Bacri, J.-C.; Luciani, N.; Gazeau, F. Nanomagnetic Sensing of Blood Plasma Protein Interactions with Iron Oxide Nanoparticles: Impact on Macrophage Uptake. ACS Nano 2012, 6, 2665-2678. [CrossRef] [PubMed]

74. Dai, Q.; Guo, J.; Yan, Y.; Ang, C.S.; Bertle-Zieschang, N.; Caruso, F. Cell-Conditioned Protein Coronas on Engineered Particles Influence Immune Responses. Biomacromolecules 2017, 18, 431-439. [CrossRef]

75. Wang, G.; Grin, J.I.; Inturi, S.; Brenneman, B.; Banda, N.K.; Michael Holers, V.; Moghimi, S.M.; Simberg, D. In vitro and in vivo di erences in murine third complement component (C3) opsonization and macrophage/leukocyte responses to anti-bodyfunctionalized iron oxide nanoworms. Front. Immunol. 2017, 8, 1-9.

76. Jackson, M.A.; Werfel, T.A.; Curvino, E.J.; Yu, F.; Kavanaugh, T.E.; Sarett, S.M.; Dockery, M.D.; Kilchrist, K.V.; Jackson, A.N.; Giorgio, T.D.; et al. Zwitterionic Nanocarrier Surface Chemistry Improves siRNA Tumor Delivery and Silencing Activity Relative to Polyethylene Glycol. ACS Nano 2017, 11, 5680-5696. [CrossRef]

77. Li, P.Y.; Fan, Z.; Cheng, H. Cell Membrane Bioconjugation and Membrane-Derived Nanomaterials for Immunotherapy. Bioconj. Chem. 2018, 29, 624-634. [CrossRef]

78. Fan, Z.; Li, P.Y.; Deng, J.; Bady, S.C.; Cheng, H. Cell membrane coating for reducing nanoparticle-induced inflammatory responses to scaffold constructs. Nano Res. 2018, 11, 5573-5583. [CrossRef]

79. Min, Y.; Roche, K.C.; Tian, S.; Eblan, M.J.; Mckinnon, K.P.; Caster, J.M.; Chai, S.; Herring, L.E.; Zhang, L.; Zhang, T.; et al. Antigen-capturing nanoparticles improve the abscopal effect and cancer immunotherapy HHS Public Access Author manuscript. Nat. Nanotechnol. 2017, 12, 877-882. [CrossRef]

80. Cedervall, T.; Lynch, I.; Lindman, S.; Berggard, T.; Thulin, E.; Nilsson, H.; Dawson, K.A.; Linse, S. Understanding the nanoparticleprotein corona using methods to quantify exchange rates and affinities of proteins for nanoparticles. Proc. Natl. Acad. Sci. USA 2007, 104, 2050-2055. [CrossRef]

81. Albanese, A.; Walkey, C.D.; Olsen, J.B.; Guo, H.; Emili, A.; Chan, W.C.W. Secreted Biomolecules Alter the Biological Identity and Cellular Interactions of Nanoparticles. ACS Nano 2014, 8, 5515-5526. [CrossRef] [PubMed] 
82. Walkey, C.D.; Olsen, J.B.; Guo, H.; Emili, A.; Chan, W.C.W. Nanoparticle Size and Surface Chemistry Determine Serum Protein Adsorption and Macrophage Uptake. J. Am. Chem. Soc. 2012, 134, 2139-2147. [CrossRef] [PubMed]

83. Matson, V.; Fessler, J.; Bao, R.; Chongsuwat, T.; Zha, Y.; Alegre, M.L.; Luke, J.J.; Gajewski, T.F. The commensal microbiome is associated with anti-PD-1 efficacy in metastatic melanoma patients. Science 2018, 359, 104-108. [CrossRef] [PubMed]

84. Sivan, A.; Corrales, L.; Hubert, N.; Williams, J.B.; Aquino-Michaels, K.; Earley, Z.M.; Benyamin, F.W.; Lei, Y.M.; Jabri, B.; Alegre, M.-L.; et al. Commensal Bifidobacterium promotes antitumor immunity and facilitates anti-PD-L1 efficacy. Science 2015, 350, 1084-1089. [CrossRef]

85. Matsumoto, K.; Yamamoto, T.; Kamata, R.; Maeda, H. Pathogenesis of Serratial Infection: Activation of the Hageman FactorPrekallikrein Cascade by Serratial Protease. J. Biochem. 1984, 96, 739-749. [CrossRef]

86. Lee, S.; Kivimäe, S.; Dolor, A.; Szoka, F.C. Macrophage-based cell therapies: The long and winding road. J. Control. Release 2016, 240, 527-540. [CrossRef]

87. Maeda, H. Tumor-Selective Delivery of Macromolecular Drugs via the EPR Effect: Background and Future Prospects. Bioconj. Chem. 2010, 21, 797-802. [CrossRef]

88. Marshall, J.S.; Green, A.M.; Pensky, J.; Williams, S.; Zinn, A.; Carlson, D.M. Measurement of Circulating Desialylated Glycoproteins and Correlation with Hepatocellular Damage. J. Clin. Investig. 1974, 54, 555-562. [CrossRef]

89. Matsumura, Y.; Hamaguchi, T.; Ura, T.; Muro, K.; Yamada, Y.; Shimada, Y.; Shirao, K.; Okusaka, T.; Ueno, H.; Ikeda, M.; et al Phase I clinical trial and pharmacokinetic evaluation of NK911, a micelle-encapsulated doxorubicin. Br. J. Cancer 2004, 91, 1775-1781. [CrossRef]

90. Liu, X.; Jiang, J.; Meng, H. Transcytosis-An effective targeting strategy that is complementary to "EPR effect" for pancreatic cancer nano drug delivery. Theranostics 2019, 9, 8018-8025. [CrossRef]

91. Kiran, A.V.V.V.R.; Kumari, G.K.; Krishnamurthy, P.T.; Khaydarov, R.R. Tumor microenvironment and nanotherapeutics: Intruding the tumor fort. Biomater. Sci. 2021, 9, 7667-7704. [CrossRef] [PubMed]

92. Matlou, G.G.; Abrahamse, H. Hybrid Inorganic-Organic Core-Shell Nanodrug Systems in Targeted Photodynamic Therapy of Cancer. Pharmaceutics 2021, 13, 1773. [CrossRef] [PubMed]

93. Park, J.; Choi, Y.; Chang, H.; Um, W.; Ryu, J.H.; Kwon, I.C. Alliance with EPR Effect: Combined Strategies to Improve the EPR Effect in the Tumor Microenvironment. Theranostics 2019, 9, 8073-8090. [CrossRef] [PubMed]

94. Shi, J.; Kantoff, P.W.; Wooster, R.; Farokhzad, O.C. Cancer nanomedicine: Progress, challenges and opportunities. Nat. Rev. Cancer 2017, 17, 20-37. [CrossRef]

95. Parodi, A.; Molinaro, R.; Sushnitha, M.; Evangelopoulos, M.; Martinez, J.O.; Arrighetti, N.; Corbo, C.; Tasciotti, E. Bio-inspired engineering of cell- and virus-like nanoparticles for drug delivery. Biomaterials 2017, 147, 155-168. [CrossRef]

96. Peer, D.; Karp, J.M.; Hong, S.; Farokhzad, O.C.; Margalit, R.; Langer, R. Nanocarriers as an emerging platform for cancer therapy. Nat. Nanotechnol. 2007, 2, 751-760. [CrossRef]

97. Grimaldi, A.M.; Incoronato, M.; Salvatore, M.; Soricelli, A. Nanoparticle-based strategies for cancer immunotherapy and immunodiagnostics. Nanomedicine 2017, 12, 2349-2365. [CrossRef]

98. Anish, C.; Khan, N.; Upadhyay, A.K.; Sehgal, D.; Panda, A.K. Delivery of Polysaccharides Using Polymer Particles: Implications on Size-Dependent Immunogenicity, Opsonophagocytosis, and Protective Immunity. Mol. Pharm. 2014, 11, 922-937. [CrossRef]

99. Goldberg, M.S. Immunoengineering: How Nanotechnology Can Enhance Cancer Immunotherapy. Cell 2015, 161, 201-204. [CrossRef]

100. Fan, Y.; Moon, J.J. Nanoparticle Drug Delivery Systems Designed to Improve Cancer Vaccines and Immunotherapy. Vaccines 2015, 3, 662-685. [CrossRef]

101. Caldorera-Moore, M.; Peppas, N.A. Micro- and nanotechnologies for intelligent and responsive biomaterial-based medical systems. Adv. Drug Deliv. Rev. 2009, 61, 1391-1401. [CrossRef] [PubMed]

102. Bhatia, S. Nanoparticles types, classification, characterization, fabrication methods and drug delivery applications. In Natural Polymer Drug Delivery Systems: Nanoparticles, Plants, and Algae; Springer International Publishing: Cham, Switzerland, 2016; pp. 33-93. [CrossRef]

103. Briolay, T.; Petithomme, T.; Fouet, M.; Nguyen-Pham, N.; Blanquart, C.; Boisgerault, N. Delivery of cancer therapies by synthetic and bio-inspired nanovectors. Mol. Cancer 2021, 20, 1-24. [CrossRef] [PubMed]

104. Kim, H.; Niu, L.; Larson, P.; Kucaba, T.A.; Murphy, K.A.; James, B.R.; Ferguson, D.M.; Griffith, T.S.; Panyam, J. Polymeric nanoparticles encapsulating novel TLR7/8 agonists as immunostimulatory adjuvants for enhanced cancer immunotherapy. Biomaterials 2018, 164, 38-53. [CrossRef]

105. Ali, O.A.; Huebsch, N.; Cao, L.; Dranoff, G.; Mooney, D.J. Infection-mimicking materials to program dendritic cells in situ. Nat. Mater. 2009, 8, 151-158. [CrossRef]

106. Zhang, Z.; Tongchusak, S.; Mizukami, Y.; Kang, Y.J.; Ioji, T.; Touma, M.; Reinhold, B.; Keskin, D.B.; Reinherz, E.L.; Sasada, T. Induction of anti-tumor cytotoxic T cell responses through PLGA-nanoparticle mediated antigen delivery. Biomaterials 2011, 32, 3666-3678. [CrossRef]

107. Perisé-Barrios, A.J.; Gómez, R.; Corbí, A.L.; de la Mata, J.; Domínguez-Soto, A.; Muñoz-Fernandez, M.A. Use of carbosilane dendrimer to switch macrophage polarization for the acquisition of antitumor functions. Nanoscale 2014, 7, 3857-3866. [CrossRef]

108. Yuba, E.; Yamaguchi, A.; Yoshizaki, Y.; Harada, A.; Kono, K. Bioactive polysaccharide-based pH-sensitive polymers for cytoplasmic delivery of antigen and activation of antigen-specific immunity. Biomaterials 2017, 120, 32-45. [CrossRef] 
109. Koshy, S.T.; Cheung, A.; Gu, L.; Graveline, A.; Mooney, D.J. Liposomal Delivery Enhances Immune Activation by STING Agonists for Cancer Immunotherapy. Adv. Biosyst. 2017, 1, 1600013. [CrossRef]

110. Sato, Y.; Hatakeyama, H.; Sakurai, Y.; Hyodo, M.; Akita, H.; Harashima, H. A pH-sensitive cationic lipid facilitates the delivery of liposomal siRNA and gene silencing activity in vitro and in vivo. J. Control Release 2012, 163, 267-276. [CrossRef]

111. Xu, Z.; Wang, Y.; Zhang, L.; Huang, L. Nanoparticle-Delivered Transforming Growth Factor- $\beta$ siRNA Enhances Vaccination against Advanced Melanoma by Modifying Tumor Microenvironment. ACS Nano 2014, 8, 3636-3645. [CrossRef]

112. Li, H.; Li, Y.; Wang, X.; Hou, Y.; Hong, X.; Gong, T.; Zhang, Z.; Sun, X. Rational design of Polymeric Hybrid Micelles to Overcome Lymphatic and Intracellular Delivery Barriers in Cancer Immunotherapy. Theranostics 2017, 7, 4383-4398. [CrossRef] [PubMed]

113. Liu, L.; He, H.; Liang, R.; Yi, H.; Meng, X.; Chen, Z.; Pan, H.; Ma, Y.; Cai, L. ROS-Inducing Micelles Sensitize Tumor-Associated Macrophages to TLR3 Stimulation for Potent Immunotherapy. Biomacromolecules 2018, 19, 2146-2155. [CrossRef] [PubMed]

114. Lin, A.Y.; Almeida, J.P.M.; Bear, A.; Liu, N.; Luo, L.; Foster, A.E.; Drezek, R.A. Gold Nanoparticle Delivery of Modified CpG Stimulates Macrophages and Inhibits Tumor Growth for Enhanced Immunotherapy. PLoS ONE 2013, 8, e63550. [CrossRef] [PubMed]

115. Chen, N.; Wei, M.; Sun, Y.; Li, F.; Pei, H.; Li, X.; Su, S.; He, Y.; Wang, L.; Shi, J.; et al. Self-Assembly of Poly-Adenine-Tailed CpG Oligonucleotide-Gold Nanoparticle Nanoconjugates with Immunostimulatory Activity. Small 2013, 10, 368-375. [CrossRef]

116. Zhao, Y.; Zhao, X.; Cheng, Y.; Guo, X.; Yuan, W. Iron Oxide Nanoparticles-Based Vaccine Delivery for Cancer Treatment. Mol. Pharm. 2018, 15, 1791-1799. [CrossRef] [PubMed]

117. Kwon, D.; Cha, B.G.; Cho, Y.; Min, J.; Park, E.-B.; Kang, S.-J.; Kim, J. Extra-Large Pore Mesoporous Silica Nanoparticles for Directing in Vivo M2 Macrophage Polarization by Delivering IL-4. Nano Lett. 2017, 17, 2747-2756. [CrossRef]

118. Lu, J.; Liu, X.; Liao, Y.-P.; Salazar, F.; Sun, B.; Jiang, W.; Chang, C.H.; Jiang, J.; Wang, X.; Wu, A.; et al. Nano-enabled pancreas cancer immunotherapy using immunogenic cell death and reversing immunosuppression. Nat. Commun. 2017, 8, 1-14. [CrossRef]

119. Fan, H.; Zhang, I.; Chen, X.; Zhang, L.; Wang, H.; da Fonseca, A.C.C.; Manuel, E.; Diamond, D.; Raubitschek, A.; Badie, B. Intracerebral CpG Immunotherapy with Carbon Nanotubes Abrogates Growth of Subcutaneous Melanomas in Mice. Clin. Cancer Res. 2012, 18, 5628-5638. [CrossRef]

120. Luo, X.; Wang, H.; Ji, D. Carbon nanotubes (CNT)-loaded ginsenosides Rb3 suppresses the PD-1/PD-L1 pathway in triple-negative breast cancer. Aging 2021, 13, 17177-17189. [CrossRef]

121. Qin, Y.; Zhou, Z.-W.; Pan, S.-T.; He, Z.-X.; Zhang, X.; Qiu, J.-X.; Duan, W.; Yang, T.; Zhou, S.-F. Graphene quantum dots induce apoptosis, autophagy, and inflammatory response via p38 mitogen-activated protein kinase and nuclear factor- $\mathrm{kB}$ mediated signaling pathways in activated THP-1 macrophages. Toxicology 2015, 327, 62-76. [CrossRef]

122. Yan, M.; Liu, Y.; Zhu, X.; Wang, X.; Liu, L.; Sun, H.; Wang, C.; Kong, D.; Ma, G. Nanoscale Reduced Graphene Oxide-Mediated Photothermal Therapy Together with IDO Inhibition and PD-L1 Blockade Synergistically Promote Antitumor Immunity. ACS Appl. Mater. Interfaces 2018, 11, 1876-1885. [CrossRef] [PubMed]

123. Hu, B.; Lara-Tejero, M.; Kong, Q.; Galán, J.E.; Liu, J. In Situ Molecular Architecture of the Salmonella Type III Secretion Machine. Cell 2017, 168, 1065-1074.e10. [CrossRef] [PubMed]

124. Luo, R.; Liu, M.; Tan, T.; Yang, Q.; Wang, Y.; Men, L.; Zhao, L.; Zhang, H.; Wang, S.; Xie, T.; et al. Emerging Significance and Therapeutic Potential of Extracellular vesicles. Int. J. Biol. Sci. 2021, 17, 2476-2486. [CrossRef] [PubMed]

125. Morishita, M.; Takahashi, Y.; Matsumoto, A.; Nishikawa, M.; Takakura, Y. Exosome-based tumor antigens-adjuvant co-delivery utilizing genetically engineered tumor cell-derived exosomes with immunostimulatory CpG DNA. Biomaterials 2016, 111, 55-65. [CrossRef]

126. Labani-Motlagh, A.; Naseri, S.; Wenthe, J.; Eriksson, E.; Loskog, A. Systemic immunity upon local oncolytic virotherapy armed with immunostimulatory genes may be supported by tumor-derived exosomes. Mol. Ther--Oncolytics 2021, 20, 508-518. [CrossRef]

127. Morse, M.A.; Garst, J.; Osada, T.; Khan, S.; Hobeika, A.; Clay, T.M.; Valente, N.; Shreeniwas, R.; Sutton, M.A.; Delcayre, A.; et al. A phase I study of dexosome immunotherapy in patients with advanced non-small cell lung cancer. J. Transl. Med. 2005, 3, 9. [CrossRef]

128. Escudier, B.; Dorval, T.; Chaput, N.; André, F.; Caby, M.-P.; Novault, S.; Flament, C.; Leboulaire, C.; Borg, C.; Amigorena, S.; et al. Vaccination of metastatic melanoma patients with autologous dendritic cell (DC) derived-exosomes: Results of thefirst phase I clinical trial. J. Transl. Med. 2005, 3, 10. [CrossRef]

129. Dai, S.; Wei, D.; Wu, Z.; Zhou, X.; Wei, X.; Huang, H.; Li, G. Phase I Clinical Trial of Autologous Ascites-derived Exosomes Combined with GM-CSF for Colorectal Cancer. Mol. Ther. 2008, 16, 782-790. [CrossRef]

130. Liu, Q.; Wang, C.; Zheng, Y.; Zhao, Y.; Wang, Y.; Hao, J.; Zhao, X.; Yi, K.; Shi, L.; Kang, C.; et al. Virus-like nanoparticle as a co-delivery system to enhance efficacy of CRISPR/Cas9-based cancer immunotherapy. Biomaterials 2020, 258, 120275. [CrossRef]

131. Alberts, P.; Tilgase, A.; Rasa, A.; Bandere, K.; Venskus, D. The advent of oncolytic virotherapy in oncology: The Rigvir ${ }^{\circledR}$ story. Eur. J. Pharmacol. 2018, 837, 117-126. [CrossRef]

132. Liang, M. Oncorine, the World First Oncolytic Virus Medicine and its Update in China. Curr. Cancer Drug Targets 2018, 18, 171-176. [CrossRef] [PubMed]

133. Kohlhapp, F.J.; Kaufman, H.L. Molecular Pathways: Mechanism of Action for Talimogene Laherparepvec, a New Oncolytic Virus Immunotherapy. Clin. Cancer Res. 2016, 22, 1048-1054. [CrossRef] [PubMed] 
134. Tanoue, K.; Shaw, A.R.; Watanabe, N.; Porter, C.; Rana, B.; Gottschalk, S.; Brenner, M.; Suzuki, M. Armed Oncolytic AdenovirusExpressing PD-L1 Mini-Body Enhances Antitumor Effects of Chimeric Antigen Receptor T Cells in Solid Tumors. Cancer Res. 2017, 77, 2040-2051. [CrossRef] [PubMed]

135. Shoae-Hassani, A.; Keyhanvar, P.; Seifalian, A.M.; Mortazavi-Tabatabaei, S.A.; Ghaderi, N.; Issazadeh, K.; Amirmozafari, N.; Verdi, J. $\lambda$ Phage Nanobioparticle Expressing Apoptin Efficiently Suppress Human Breast Carcinoma Tumor Growth In Vivo. PLoS ONE 2013, 8, e79907. [CrossRef]

136. Ghaemi, A.; Soleimanjahi, H.; Gill, P.; Hassan, Z.; Jahromi, S.R.M.; Roohvand, F. Recombinant $\lambda$-phage nanobioparticles for tumor therapy in mice models. Genet. Vaccines Ther. 2010, 8, 3. [CrossRef]

137. Van Houten, N.E.; Henry, K.A.; Smith, G.P.; Scott, J.K. Engineering filamentous phage carriers to improve focusing of antibody responses against peptides. Vaccine 2010, 28, 2174-2185. [CrossRef]

138. Lee, Y.-R.; Lee, Y.-H.; Im, S.-A.; Yang, I.-H.; Ahn, G.W.; Kim, K.; Lee, C.-K. Biodegradable nanoparticles containing TLR3 or TLR9 agonists together with antigen enhance MHC-restricted presentation of the antigen. Arch. Pharm. Res. 2010, 33, 1859-1866. [CrossRef]

139. Heo, M.B.; Lim, Y.T. Programmed nanoparticles for combined immunomodulation, antigen presentation and tracking of immunotherapeutic cells. Biomaterials 2013, 35, 590-600. [CrossRef]

140. Kokate, R.A.; Chaudhary, P.; Sun, X.L.; Thamake, S.I.; Maji, S.; Chib, R.; Vishwanatha, J.K.; Jones, H.P. Rationalizing the use of functionalized poly-lactic-coglycolic acid nanoparticles for dendritic cell-based targeted anticancer therapy. Nanomedicine 2016, 11, 479-494. [CrossRef]

141. Colzani, B.; Pandolfi, L.; Hoti, A.; Iovene, P.A.; Natalello, A.; Avvakumova, S.; Colombo, M.; Prosperi, D. Investigation of antitumor activities of trastuzumab delivered by PLGA nanoparticles. Int. J. Nanomed. 2018, 13, 957-973. [CrossRef]

142. Cruz, L.J.; Tacken, P.J.; Fokkink, R.; Joosten, B.; Stuart, M.C.; Albericio, F.; Torensma, R.; Figdor, C.G. Targeted PLGA nano- but not microparticles specifically deliver antigen to human dendritic cells via DC-SIGN in vitro. J. Control. Release 2010, 144, 118-126. [CrossRef] [PubMed]

143. Bandyopadhyay, A.; Fine, R.L.; Demento, S.; Bockenstedt, L.K.; Fahmy, T.M. The impact of nanoparticle ligand density on dendritic-cell targeted vaccines. Biomaterials 2011, 32, 3094-3105. [CrossRef] [PubMed]

144. Mueller, M.; Schlosser, E.; Gander, B.; Groettrup, M. Tumor eradication by immunotherapy with biodegradable PLGA microspheres-an alternative to incomplete Freund's adjuvant. Int. J. Cancer 2011, 129, 407-416. [CrossRef] [PubMed]

145. Luo, L.; Zhu, C.; Yin, H.; Jiang, M.; Zhang, J.; Qin, B.; Luo, Z.; Yuan, X.; Yang, J.; Li, W.; et al. Laser Immunotherapy in Combination with Perdurable PD-1 Blocking for the Treatment of Metastatic Tumors. ACS Nano 2018, 12, 7647-7662. [CrossRef] [PubMed]

146. Nanjwade, B.K.; Bechra, H.M.; Derkar, G.K.; Manvi, F.; Nanjwade, V.K. Dendrimers: Emerging polymers for drug-delivery systems. Eur. J. Pharm. Sci. 2009, 38, 185-196. [CrossRef] [PubMed]

147. Lee, I.-H.; An, S.; Yu, M.K.; Kwon, H.; Im, S.-H.; Jon, S. Targeted chemoimmunotherapy using drug-loaded aptamer-dendrimer bioconjugates. J. Control. Release 2011, 155, 435-441. [CrossRef]

148. Torchilin, V.P. Recent advances with liposomes as pharmaceutical carriers. Nat. Rev. Drug Discov. 2005, 4, 145-160. [CrossRef]

149. Bulbake, U.; Doppalapudi, S.; Kommineni, N.; Khan, W. Liposomal Formulations in Clinical Use: An Updated Review. Pharmaceutics 2017, 9, 12. [CrossRef]

150. Bozzuto, G.; Molinari, A. Liposomes as nanomedical devices. Int. J. Nanomed. 2015, 10, 975-999. [CrossRef]

151. Yuba, E.; Kanda, Y.; Yoshizaki, Y.; Teranishi, R.; Harada, A.; Sugiura, K.; Izawa, T.; Yamate, J.; Sakaguchi, N.; Koiwai, K.; et al. $\mathrm{pH}$-sensitive polymer-liposome-based antigen delivery systems potentiated with interferon- $\gamma$ gene lipoplex for efficient cancer immunotherapy. Biomaterials 2015, 67, 214-224. [CrossRef]

152. Peng, J.; Xiao, Y.; Li, W.; Yang, Q.; Tan, L.; Jia, Y.; Qu, Y.; Qian, Z. Photosensitizer Micelles Together with IDO Inhibitor Enhance Cancer Photothermal Therapy and Immunotherapy. Adv. Sci. 2018, 5, 1700891. [CrossRef] [PubMed]

153. Kodiha, M.; Wang, Y.M.; Hutter, E.; Maysinger, D.; Stochaj, U. Off to the Organelles-Killing Cancer Cells with Targeted Gold Nanoparticles. Theranostics 2015, 5, 357-370. [CrossRef] [PubMed]

154. Kong, F.-Y.; Zhang, J.-W.; Li, R.-F.; Wang, Z.-X.; Wang, W.-J.; Wang, W. Unique Roles of Gold Nanoparticles in Drug Delivery, Targeting and Imaging Applications. Molecules 2017, 22, 1445. [CrossRef] [PubMed]

155. Dykman, L.A.; Staroverov, S.; Fomin, A.S.; Khanadeev, V.A.; Khlebtsov, B.; Bogatyrev, V.A. Gold nanoparticles as an adjuvant: Influence of size, shape, and technique of combination with $\mathrm{CpG}$ on antibody production. Int. Immunopharmacol. 2018, 54, 163-168. [CrossRef]

156. Jia, J.; Liu, G.; Xu, W.; Tian, X.; Li, S.; Han, F.; Feng, Y.; Dong, X.; Chen, H. Fine-Tuning the Homometallic Interface of Au-on-Au Nanorods and Their Photothermal Therapy in the NIR-II Window. Angew. Chem. Int. Ed. 2020, 59, 14443-14448. [CrossRef]

157. Chen, J.; Wang, D.; Xi, J.; Au, L.; Siekkinen, A.; Warsen, A.; Li, Z.-Y.; Zhang, H.; Xia, Y.; Li, X. Immuno Gold Nanocages with Tailored Optical Properties for Targeted Photothermal Destruction of Cancer Cells. Nano Lett. 2007, 7, 1318-1322. [CrossRef]

158. Rezaei, M.; Hosseini, S.N.; Khavari-Nejad, R.A.; Najafi, F.; Mahdavi, M. HBs antigen and mannose loading on the surface of iron oxide nanoparticles in order to immuno-targeting: Fabrication, characterization, cellular and humoral immunoassay. Artif. Cells Nanomed. Biotechnol. 2019, 47, 1543-1558. [CrossRef] [PubMed]

159. Warheit, D.B.; Hartsky, M.A. Role of alveolar macrophage chemotaxis and phagocytosis in pulmonary clearance responses to inhaled particles: Comparisons among rodent species. Microsc. Res. Tech. 1993, 26, 412-422. [CrossRef] [PubMed] 
160. Slowing, I.I.; Vivero-Escoto, J.L.; Wu, C.-W.; Lin, V.S.-Y. Mesoporous silica nanoparticles as controlled release drug delivery and gene transfection carriers. Adv. Drug Deliv. Rev. 2008, 60, 1278-1288. [CrossRef] [PubMed]

161. Croissant, J.; Fatieiev, Y.; Khashab, N. Degradability and Clearance of Silicon, Organosilica, Silsesquioxane, Silica Mixed Oxide, and Mesoporous Silica Nanoparticles. Adv. Mater. 2017, 29, 1604634. [CrossRef]

162. Vallhov, H.; Gabrielsson, S.; Strømme, M.; Scheynius, A.; Garcia-Bennett, A.E. Mesoporous Silica Particles Induce Size Dependent Effects on Human Dendritic Cells. Nano Lett. 2007, 7, 3576-3582. [CrossRef] [PubMed]

163. Guo, H.-C.; Feng, X.-M.; Sun, S.-Q.; Wei, Y.-Q.; Sun, D.-H.; Liu, X.-T.; Liu, Z.-X.; Luo, J.-X.; Yin, H. Immunization of mice by Hollow Mesoporous Silica Nanoparticles as carriers of Porcine Circovirus Type 2 ORF2 Protein. Virol. J. 2012, 9, 108. [CrossRef] [PubMed]

164. Hassan, H.A.; Smyth, L.; Wang, T.-W.; da Costa, P.M.C.; Ratnasothy, K.; Diebold, S.S.; Lombardi, G.; Al-Jamal, K.T. Dual stimulation of antigen presenting cells using carbon nanotube-based vaccine delivery system for cancer immunotherapy. Biomaterials 2016, 104, 310-322. [CrossRef] [PubMed]

165. Wang, C.; Xu, L.; Liang, C.; Xiang, J.; Peng, R.; Liu, Z. Immunological Responses Triggered by Photothermal Therapy with Carbon Nanotubes in Combination with Anti-CTLA-4 Therapy to Inhibit Cancer Metastasis. Adv. Mater. 2014, 26, 8154-8162. [CrossRef]

166. Choi, J.R.; Yong, K.W.; Choi, J.Y.; Nilghaz, A.; Lin, Y.; Xu, J.; Lu, X. Black Phosphorus and its Biomedical Applications. Theranostics 2018, 8, 1005-1026. [CrossRef]

167. Chimene, D.; Alge, D.L.; Gaharwar, A.K. Two-Dimensional nanomaterials for biomedical applications: Emerging trends and future prospects. Adv. Mater. 2015, 27, 7261-7284. [CrossRef]

168. Kim, M.-G.; Park, J.Y.; Shon, Y.; Shim, G.; Oh, Y.-K. Pharmaceutical applications of graphene-based nanosheets. Curr. Pharm. Biotechnol. 2014, 14, 1016-1026. [CrossRef]

169. Dash, B.; Jose, G.; Lu, Y.-J.; Chen, J.-P. Functionalized Reduced Graphene Oxide as a Versatile Tool for Cancer Therapy. Int. J. Mol. Sci. 2021, 22, 2989. [CrossRef]

170. Jaworski, S.; Sawosz, E.; Grodzik, M.; Winnicka, A.; Prasek, M.; Wierzbicki, M.; Chwalibog, A. In vitro evaluation of the effects of graphene platelets on glioblastoma multiforme cells. Int. J. Nanomed. 2013, 8, 413-420. [CrossRef]

171. Yang, K.; Wan, J.; Zhang, S.; Zhang, Y.; Lee, S.-T.; Liu, Z. In Vivo Pharmacokinetics, Long-Term Biodistribution, and Toxicology of PEGylated Graphene in Mice. ACS Nano 2010, 5, 516-522. [CrossRef]

172. Gurunathan, S.; Han, J.W.; Eppakayala, V.; Kim, J.-H. Green synthesis of graphene and its cytotoxic effects in human breast cancer cells. Int. J. Nanomed. 2013, 8, 1015-1027. [CrossRef] [PubMed]

173. Liu, Y.; Luo, Y.; Wu, J.; Wang, Y.; Yang, X.; Yang, R.; Wang, B.; Yang, J.; Zhang, N. Graphene oxide can induce in vitro and in vivo mutagenesis. Sci. Rep. 2013, 3, 3469. [CrossRef] [PubMed]

174. Wang, L.; Wang, M.; Zhou, B.; Zhou, F.; Murray, C.; Towner, R.A.; Smith, N.; Saunders, D.; Xie, G.; Chen, W.R. PEGylated reduced-graphene oxide hybridized with Fe3O4nanoparticles for cancer photothermal-immunotherapy. J. Mater. Chem. B 2019, 7 , 7406-7414. [CrossRef] [PubMed]

175. Charych, D.H.; Hoch, U.; Langowski, J.L.; Lee, S.R.; Addepalli, M.K.; Kirk, P.B.; Sheng, D.; Liu, X.; Sims, P.W.; VanderVeen, L.A.; et al. NKTR-214, an engineered cytokine with biased IL2 receptor binding, increased tumor exposure, and marked efficacy in mouse tumor models. Clin. Cancer Res 2016, 22, 680-690. [CrossRef] [PubMed]

176. Charych, D.; Khalili, S.; Dixit, V.; Kirk, P.; Chang, T.; Langowski, J.; Rubas, W.; Doberstein, S.K.; Eldon, M.; Hoch, U.; et al. Modeling the receptor pharmacology, pharmacokinetics, and pharmacodynamics of NKTR-214, a kinetically-controlled interleukin-2 (IL2) receptor agonist for cancer immunotherapy. PLOS ONE 2017, 12, e0179431. [CrossRef] [PubMed]

177. Bentebibel, S.-E.; Hurwitz, M.E.; Bernatchez, C.; Haymaker, C.; Hudgens, C.W.; Kluger, H.M.; Tetzlaff, M.T.; Tagliaferri, M.A.; Zalevsky, J.; Hoch, U.; et al. A first-in-human study and biomarker analysis of NKTR-214, a novel IL2R $\beta \gamma$-biased cytokine, in patients with advanced or metastatic solid tumors. Cancer Discov. 2019, 9, 711-721. [CrossRef]

178. Bonvalot, S.; Le Pechoux, C.; De Baere, T.; Kantor, G.; Buy, X.; Stoeckle, E.; Terrier, P.; Sargos, P.; Coindre, J.M.; Lassau, N.; et al First-in-Human Study Testing a New Radioenhancer Using Nanoparticles (NBTXR3) Activated by Radiation Therapy in Patients with Locally Advanced Soft Tissue Sarcomas. Clin. Cancer Res. 2016, 23, 908-917. [CrossRef]

179. Marill, J.; Mohamed Anesary, N.; Paris, S. DNA damage enhancement by radiotherapy-activated hafnium oxide nanoparticles improves cGAS-STING pathway activation in human colorectal cancer cells. Radiother. Oncol. 2019, 141, 262-266. [CrossRef]

180. Duan, X.; Chan, C.; Guo, N.; Han, W.; Weichselbaum, R.R.; Lin, W. Photodynamic Therapy Mediated by Nontoxic Core-Shell Nanoparticles Synergizes with Immune Checkpoint Blockade to Elicit Antitumor Immunity and Antimetastatic Effect on Breast Cancer. J. Am. Chem. Soc. 2016, 138, 16686-16695. [CrossRef]

181. Wang, A.Z.; Langer, R.; Farokhzad, O.C. Nanoparticle Delivery of Cancer Drugs. Annu. Rev. Med. 2012, 63, 185-198. [CrossRef]

182. He, C.; Duan, X.; Guo, N.; Chan, C.; Poon, C.; Weichselbaum, R.R.; Lin, W. Core-shell nanoscale coordination polymers combine chemotherapy and photodynamic therapy to potentiate checkpoint blockade cancer immunotherapy. Nat. Commun. 2016, 7, 12499. [CrossRef] [PubMed]

183. Lu, K.; He, C.; Guo, N.; Chan, C.; Ni, K.; Lan, G.; Tang, H.; Pelizzari, C.; Fu, Y.-X.; Spiotto, M.T.; et al. Low-dose X-ray radiotherapy-radiodynamic therapy via nanoscale metal-organic frameworks enhances checkpoint blockade immunotherapy. Nat. Biomed. Eng. 2018, 2, 600-610. [CrossRef] [PubMed] 
184. Hewitt, S.L.; Bai, A.; Bailey, D.; Ichikawa, K.; Zielinski, J.; Karp, R.; Apte, A.; Arnold, K.; Zacharek, S.J.; Iliou, M.S.; et al. Durable anticancer immunity from intratumoral administration of IL-23, IL-36 $\gamma$, and OX40L mRNAs. Sci. Transl. Med. 2019, 11, eaat9143. [CrossRef] [PubMed]

185. MacDiarmid, A.J.; Brahmbhatt, H. Minicells: Versatile vectors for targeted drug or si/shRNA cancer therapy. Curr. Opin. Biotechnol. 2011, 22, 909-916. [CrossRef]

186. Farley, M.M.; Hu, B.; Margolin, W.; Liu, J. Minicells, Back in Fashion. J. Bacteriol. 2016, 198, 1186-1195. [CrossRef]

187. Lara-Tejero, M.; Kato, J.; Wagner, S.; Liu, X.; Galán, J.E. A Sorting Platform Determines the Order of Protein Secretion in Bacterial Type III Systems. Science 2011, 331, 1188-1191. [CrossRef]

188. Carleton, H.A.; Lara-Tejero, M.; Liu, X.; Galán, J.E. Engineering the type III secretion system in non-replicating bacterial minicells for antigen delivery. Nat. Commun. 2013, 4, 1-8. [CrossRef]

189. Möller, A.; Lobb, R.J. The evolving translational potential of small extracellular vesicles in cancer. Nat. Cancer 2020, 20, 697-709. [CrossRef]

190. Nikfarjam, S.; Rezaie, J.; Kashanchi, F.; Jafari, R. Dexosomes as a cell-free vaccine for cancer immunotherapy. J. Exp. Clin. Cancer Res. 2020, 39, 1-20. [CrossRef]

191. Skogberg, G.; Lundberg, V.; Berglund, M.; Gudmundsdottir, J.; Telemo, E.; Lindgren, S.; Ekwall, O. Human thymic epithelial primary cells produce exosomes carrying tissue-restricted antigens. Immunol. Cell Biol. 2015, 93, 727-734. [CrossRef]

192. Hu, X.-Y.; Li, W.-Y.; Zhu, Q.-B.; Jin, L.-Y.; Yang, Y.; Xu, X.-Y. Exosomes derived from human induced pluripotent stem cell-derived neural progenitor cells protect neuronal function under ischemic conditions. Neural Regen. Res. 2021, 16, 2064-2070. [CrossRef] [PubMed]

193. Wang, C.; Huang, X.; Wu, Y.; Wang, J.; Li, F.; Guo, G. Tumor Cell-associated Exosomes Robustly Elicit Anti-tumor Immune Responses through Modulating Dendritic Cell Vaccines in Lung Tumor. Int. J. Biol. Sci. 2020, 16, 633-643. [CrossRef] [PubMed]

194. Akbari, A.; Rezaie, J. Potential therapeutic application of mesenchymal stem cell-derived exosomes in SARS-CoV-2 pneumonia. Stem Cell Res. Ther. 2020, 11, 356. [CrossRef] [PubMed]

195. Ha, D.; Yang, N.; Nadithe, V. Exosomes as therapeutic drug carriers and delivery vehicles across biological membranes: Current perspectives and future challenges. Acta Pharm. Sin. B 2016, 6, 287-296. [CrossRef]

196. Cabeza, L.; Perazzoli, G.; Peña, M.; Cepero, A.; Luque, C.; Melguizo, C.; Prados, J. Cancer therapy based on extracellular vesicles as drug delivery vehicles. J. Control. Release 2020, 327, 296-315. [CrossRef]

197. O'Brien, K.; Breyne, K.; Ughetto, S.; Laurent, L.C.; Breakefield, X.O. RNA delivery by extracellular vesicles in mammalian cells and its applications. Nat. Rev. Mol. Cell Biol. 2020, 21, 585-606. [CrossRef]

198. Théry, C.; Witwer, K.W.; Aikawa, E.; Alcaraz, M.J.; Anderson, J.D.; Andriantsitohaina, R.; Antoniou, A.; Arab, T.; Archer, F.; Atkin-Smith, G.K.; et al. Minimal information for studies of extracellular vesicles 2018 (MISEV2018): A position statement of the International Society for Extracellular Vesicles and update of the MISEV2014 guidelines. J. Extracell. Vesicles 2018, 7, 1535750. [CrossRef]

199. Logtenberg, M.E.W.; Scheeren, F.A.; Schumacher, T.N. The CD47-SIRP alpha Immune Checkpoint. Immunity 2020, 52, 742-752. [CrossRef]

200. Raposo, G.; Nijman, H.W.; Stoorvogel, W.; Liejendekker, R.; Harding, C.V.; Melief, C.J.; Geuze, H.J. B lymphocytes secrete antigen-presenting vesicles. J. Exp. Med. 1996, 183, 1161-1172. [CrossRef]

201. Yang, H.; Fu, H.; Wang, B.; Zhang, X.; Mao, J.; Li, X.; Wang, M.; Sun, Z.; Qian, H.; Xu, W. Exosomal miR-423-5p targets SUFU to promote cancer growth and metastasis and serves as a novel marker for gastric cancer. Mol. Carcinog. 2018, 57, 1223-1236. [CrossRef]

202. Yang, Y.; Xiu, F.; Cai, Z.; Wang, J.; Wang, Q.; Fu, Y.-X.; Cao, X. Increased induction of antitumor response by exosomes derived from interleukin-2 gene-modified tumor cells. J. Cancer Res. Clin. Oncol. 2007, 133, 389-399. [CrossRef] [PubMed]

203. Zitvogel, L.; Regnault, A.; Lozier, A.; Wolfers, J.; Flament, C.; Tenza, D.; Ricciardi-Castagnoli, P.; Raposo, G.; Amigorena, S. Eradication of established murine tumors using a novel cell-free vaccine: Dendritic cell derived exosomes. Nat. Med. 1998, 4 , 594-600. [CrossRef] [PubMed]

204. Besse, B.; Charrier, M.; Lapierre, V.; Dansin, E.; Lantz, O.; Planchard, D.; Le Chevalier, T.; Livartoski, A.; Barlesi, F.; Laplanche, A.; et al. Dendritic cell-derived exosomes as maintenance immunotherapy after first line chemotherapy in NSCLC. OncoImmunology 2016, 5, e1071008. [CrossRef] [PubMed]

205. Tang, X.-J.; Sun, X.-Y.; Huang, K.-M.; Zhang, L.; Yang, Z.-S.; Zou, D.-D.; Wang, B.; Warnock, G.L.; Dai, L.-J.; Luo, J. Therapeutic potential of CAR-T cell-derived exosomes: A cell-free modality for targeted cancer therapy. Oncotarget 2015, 6, 44179-44190. [CrossRef]

206. Harn, H.-J.; Chen, Y.-S.; Lin, E.-Y.; Chiou, T.-W. Exosomes in clinical trial and their production in compliance with good manufacturing practice. Tzu Chi Med. J. 2020, 32, 113-120. [CrossRef]

207. Smith, D.M.; Simon, J.K.; Baker, J.R., Jr. Applications of nanotechnology for immunology. Nat. Rev. Immunol. 2013, 13, 592-605. [CrossRef]

208. Lizotte, P.; Wen, A.M.; Sheen, M.R.; Fields, J.; Rojanasopondist, P.; Steinmetz, N.F.; Fiering, S. In situ vaccination with cowpea mosaic virus nanoparticles suppresses metastatic cancer. Nat. Nanotechnol. 2015, 11, 295-303. [CrossRef] 
209. Brown, M.C.; Holl, E.K.; Boczkowski, D.; Dobrikova, E.; Mosaheb, M.; Chandramohan, V.; Bigner, D.D.; Gromeier, M.; Nair, S.K. Cancer immunotherapy with recombinant poliovirus induces IFN-dominant activation of dendritic cells and tumor antigenspecific CTLs. Sci. Transl. Med. 2017, 9, 303-395. [CrossRef]

210. Bommareddy, P.K.; Shettigar, M.; Kaufman, H.L. Integrating oncolytic viruses in combination cancer immunotherapy. Nat. Rev. Immunol. 2018, 18, 498-513. [CrossRef]

211. El-Shemi, A.G.; Ashshi, A.M.; Na, Y.; Li, Y.; Basalamah, M.; Al-Allaf, F.; Mohammed, A.A.; Jung, B.-K.; Yun, C.-O. Combined therapy with oncolytic adenoviruses encoding TRAIL and IL-12 genes markedly suppressed human hepatocellular carcinoma both in vitro and in an orthotopic transplanted mouse model. J. Exp. Clin. Cancer Res. 2016, 35, 1-16. [CrossRef]

212. Goel, A.; Carlson, S.K.; Classic, K.L.; Greiner, S.; Naik, S.; Power, A.T.; Bell, J.C.; Russell, S.J. Radioiodide imaging and radiovirotherapy of multiple myeloma using VSV( $\Delta 51)$-NIS, an attenuated vesicular stomatitis virus encoding the sodium iodide symporter gene. Blood 2007, 110, 2342-2350. [CrossRef] [PubMed]

213. Kaufman, H.L.; Bommareddy, P.K. Two roads for oncolytic immunotherapy development. J. Immunother. Cancer 2019, 7, 26, Correction in 2021, 9, e0515-2corr1. [CrossRef] [PubMed]

214. Macedo, N.; Miller, D.M.; Haq, R.; Kaufman, H.L. Clinical landscape of oncolytic virus research in 2020. J. Immunother. Cancer 2020, 8, e001486. [CrossRef] [PubMed]

215. Andtbacka, R.H.; Kaufman, H.L.; Collichio, F.; Amatruda, T.; Senzer, N.; Chesney, J.; Delman, K.A.; Spitler, L.E.; Puzanov, I.; Agarwala, S.S.; et al. Talimogene Laherparepvec Improves Durable Response Rate in Patients with Advanced Melanoma. J. Clin. Oncol. 2015, 33, 2780-2788. [CrossRef] [PubMed]

216. Martinez-Quintanilla, J.; Seah, I.; Chua, M.; Shah, K. Oncolytic viruses: Overcoming translational challenges. J. Clin. Investig. 2019, 129, 1407-1418. [CrossRef]

217. Yokoda, R.; Nagalo, B.M.; Vernon, B.; Oklu, R.; Albadawi, H.; DeLeon, T.T.; Zhou, Y.; Egan, J.B.; Duda, D.G.; Borad, M.J. Oncolytic virus delivery: From nano-pharmacodynamics to enhanced oncolytic effect. Oncolytic Virother. 2017, 6, 39-49. [CrossRef]

218. Benencia, F.; Courrèges, M.C.; Fraser, N.W.; Coukos, G. Herpes virus oncolytic therapy reverses tumor immune dysfunction and facilitates tumor antigen presentation. Cancer Biol. Ther. 2008, 7, 1194-1205. [CrossRef]

219. Du, W.; Seah, I.; Bougazzoul, O.; Choi, G.; Meeth, K.; Bosenberg, M.W.; Wakimoto, H.; Fisher, D.; Shah, K. Stem cell-released oncolytic herpes simplex virus has therapeutic efficacy in brain metastatic melanomas. Proc. Natl. Acad. Sci. USA 2017, 114, E6157-E6165. [CrossRef]

220. Goracci, M.; Pignochino, Y.; Marchiò, S. Phage Display-Based Nanotechnology Applications in Cancer Immunotherapy. Molecules 2020, 25, 843. [CrossRef]

221. Akiyama, Y.; Miyata, H.; Komiyama, M.; Nogami, M.; Ozawa, K.; Oshita, C.; Kume, A.; Ashizawa, T.; Sakura, N.; Mochizuki, T.; et al. The identification of affinity peptide ligands specific to the variable region ofhuman antibodies. Biomed. Res. 2014, 35, 105-116. [CrossRef]

222. Jafari, N.; Abediankenari, S. Phage Particles as Vaccine Delivery Vehicles: Concepts, Applications and Prospects. Asian Pac. J. Cancer Prev. 2016, 16, 8019-8029. [CrossRef] [PubMed]

223. Duan, X.; Chan, C.; Lin, W. Nanoparticle-Mediated Immunogenic Cell Death Enables and Potentiates Cancer Immunotherapy Angew. Chem. Int. Ed. 2018, 58, 670-680. [CrossRef] [PubMed]

224. Rios-Doria, J.; Durham, N.; Wetzel, L.; Rothstein, R.; Chesebrough, J.; Holoweckyj, N.; Zhao, W.; Leow, C.C.; Hollingsworth, R. Doxil Synergizes with Cancer Immunotherapies to Enhance Antitumor Responses in Syngeneic Mouse Models. Neoplasia 2015 17, 661-670. [CrossRef] [PubMed]

225. Zhao, X.; Yang, K.; Zhao, R.; Ji, T.; Wang, X.; Yang, X.; Zhang, Y.; Cheng, K.; Liu, S.; Hao, J.; et al. Inducing enhanced immunogenic cell death with nanocarrier-based drug delivery systems for pancreatic cancer therapy. Biomaterials 2016, 102, 187-197. [CrossRef]

226. Chatterjee, D.K.; Fong, L.S.; Zhang, Y. Nanoparticles in photodynamic therapy: An emerging paradigm. Adv. Drug Deliv. Rev. 2008, 60, 1627-1637. [CrossRef]

227. Formenti, S.C.; Demaria, S. Combining Radiotherapy and Cancer Immunotherapy: A Paradigm Shift. JNCI J. Natl. Cancer Inst. 2013, 105, 256-265. [CrossRef]

228. Vanpouille-Box, C.; Diamond, J.M.; Pilones, K.A.; Zavadil, J.; Babb, J.; Formenti, S.C.; Barcellos-Hoff, M.H.; DeMaria, S. TGF $\beta$ Is a Master Regulator of Radiation Therapy-Induced Antitumor Immunity. Cancer Res. 2015, 75, 2232-2242. [CrossRef]

229. Rodriguez-Ruiz, E.M.; Rodríguez, I.; Mayorga, L.; Labiano, T.; Barbes, B.; Etxeberria, I.; Ponz-Sarvise, M.; Azpilikueta, A.; Bolaños, E.; Sanmamed, M.F.; et al. TGF $\beta$ Blockade Enhances Radiotherapy Abscopal Efficacy Effects in Combination with Anti-PD1 and Anti-CD137 Immunostimulatory Monoclonal Antibodies. Mol. Cancer Ther. 2019, 18, 621-631. [CrossRef]

230. Obeid, M.; Panaretakis, T.; Joza, N.; Tufi, R.; Tesniere, A.; van Endert, P.; Zitvogel, L.; Kroemer, G. Calreticulin exposure is required for the immunogenicity of gamma-irradiation and UVC light-induced apoptosis. Cell Death Differ. 2007, 14, 1848-1850. [CrossRef]

231. Yang, G.; Xu, L.; Chao, Y.; Xu, J.; Sun, X.; Wu, Y.; Peng, R.; Liu, Z. Hollow $\mathrm{MnO}_{2}$ as a tumor-microenvironment-responsive biodegradable nano-platform for combination therapy favoring antitumor immune responses. Nat. Commun. 2017, 8, 1-13. [CrossRef]

232. Mathios, D.; Kim, J.E.; Mangraviti, A.; Phallen, J.; Park, C.-K.; Jackson, C.M.; Garzon-Muvdi, T.; Kim, E.; Theodros, D.; Polanczyk, M.; et al. Anti-PD-1 antitumor immunity is enhanced by local and abrogated by systemic chemotherapy in GBM. Sci. Transl. Med. 2016, 8, 370ra180. [CrossRef] [PubMed]

233. Mulder, W.J.M.; Gnjatic, S. From local to global. Nat. Nanotechnol. 2017, 12, 840-841. [CrossRef] [PubMed] 
234. Bonvalot, S.; Rutkowski, P.; Thariat, J.; Carrère, S.; Ducassou, A.; Sunyach, M.-P.; Agoston, P.; Hong, A.; Mervoyer, A.; Rastrelli, M.; et al. NBTXR3, a first-in-class radioenhancer hafnium oxide nanoparticle, plus radiotherapy versus radiotherapy alone in patients with locally advanced soft-tissue sarcoma (Act.In.Sarc): A multicentre, phase 2-3, randomised, controlled trial. Lancet Oncol. 2019, 20, 1148-1159. [CrossRef]

235. Taylor, C.T.; Colgan, S.P. Regulation of immunity and inflammation by hypoxia in immunological niches. Nat. Rev. Immunol. 2017, 17, 774-785. [CrossRef]

236. Barsoum, I.B.; Smallwood, C.A.; Siemens, D.R.; Graham, C.H. A mechanism of hypoxia-mediated escape from adaptive immunity in cancer cells. Canc. Res. 2014, 74, 665-674. [CrossRef]

237. Chen, Q.; Feng, L.; Liu, J.; Zhu, W.; Dong, Z.; Wu, Y.; Liu, Z. Intelligent albumin- $\mathrm{MnO}_{2}$ nanoparticles as $\mathrm{pH}-/ \mathrm{H}_{2} \mathrm{O}_{2}$-responsive dissociable nanocarriers to modulate tumor hypoxia for effective combination therapy. Adv Mater. 2016, 28, 7129-7136, Correction Adv Mater. 2018, 30. [CrossRef]

238. Hei, Y.; Teng, B.; Zeng, Z.; Zhang, S.; Li, Q.; Pan, J.; Luo, Z.; Xiong, C.; Wei, S. Multifunctional immunoliposomes combining catalase and PD-L1 antibodies overcome tumor hypoxia and enhance immunotherapeutic effects against melanoma. Int. J. Nanomed. 2020, 15, 1677-1691. [CrossRef]

239. Gerweck, E.L.; Seetharaman, K. Cellular pH gradient in tumor versus normal tissue: Potential exploitation for the treatment of cancer. Cancer Res. 1996, 56, 1194-1198.

240. Chang, H.; Zou, Z.; Wang, Q.; Li, J.; Jin, H.; Yin, Q.; Xing, D. Targeting and Specific Activation of Antigen-Presenting Cells by Endogenous Antigen-Loaded Nanoparticles Elicits Tumor-Specific Immunity. Adv. Sci. 2019, 7, 1900069. [CrossRef]

241. Li, L.; Sun, W.; Zhong, J.; Yang, Q.; Zhu, X.; Zhou, Z.; Zhang, Z.; Huang, Y. Multistage nanovehicle delivery system based on stepwise size reduction and charge reversal for programmed nuclear targeting of systemically administered anticancer drugs. Adv. Funct. Mater. 2015, 25, 4101-4113. [CrossRef]

242. Sallusto, F.; Lanzavecchia, A. Efficient presentation of soluble antigen by cultured human dendritic cells is maintained by granulocyte/macrophage colony-stimulating factor plus interleukin 4 and downregulated by tumor necrosis factor alpha. J. Exp. Med. 1994, 179, 1109-1118. [CrossRef] [PubMed]

243. Kandalaft, L.E.; Powell, J.D.J.; Chiang, C.L.; Tanyi, J.; Kim, S.; Bosch, M.; Montone, K.; Mick, R.; Levine, B.L.; Torigian, D.A.; et al. Autologous lysate-pulsed dendritic cell vaccination followed by adoptive transfer of vaccine-primed ex vivo co-stimulated T cells in recurrent ovarian cancer. OncoImmunology 2013, 2, e22664. [CrossRef] [PubMed]

244. Moon, J.J.; Huang, B.; Irvine, D.J. Engineering Nano- and Microparticles to Tune Immunity. Adv. Mater. 2012, 24, 3724-3746. [CrossRef] [PubMed]

245. Cruz, L.J.; Rosalia, R.A.; Kleinovink, J.W.; Rueda, F.; Löwik, C.W.; Ossendorp, F. Targeting nanoparticles to CD40, DEC-205 or CD11c molecules on dendritic cells for efficient CD8 ${ }^{+}$T cell response: A comparative study. J. Control. Release 2014, 192, 209-218. [CrossRef] [PubMed]

246. Lewis, J.S.; Zaveri, T.; Crooks, C.P.; Keselowsky, B.G. Microparticle surface modifications targeting dendritic cells for nonactivating applications. Biomaterials 2012, 33, 7221-7232. [CrossRef] [PubMed]

247. Rosalia, R.A.; Cruz, L.J.; van Duikeren, S.; Tromp, A.T.; Silva, A.L.; Jiskoot, W.; de Gruijl, T.; Löwik, C.; Oostendorp, J.; van der Burg, S.H.; et al. CD40-targeted dendritic cell delivery of PLGA-nanoparticle vaccines induce potent anti-tumor responses. Biomaterials 2015, 40, 88-97. [CrossRef] [PubMed]

248. Zheng, X.; Vladau, C.; Shunner, A.; Min, W.-P. siRNA Specific Delivery System for Targeting Dendritic Cells. Methods Mol. Biol. 2010, 623, 173-188. [CrossRef]

249. Bonehill, A.; Van Nuffel, A.; Corthals, J.; Tuyaerts, S.; Heirman, C.; François, V.; Colau, D.; Van Der Bruggen, P.; Neyns, B.; Thielemans, K. Single-Step Antigen Loading and Activation of Dendritic Cells by mRNA Electroporation for the Purpose of Therapeutic Vaccination in Melanoma Patients. Clin. Cancer Res. 2009, 15, 3366-3375. [CrossRef]

250. Hoopes, P.J.; Wagner, R.J.; Duval, K.; Kang, K.; Gladstone, D.J.; Moodie, K.L.; Crary-Burney, M.; Ariaspulido, H.; Veliz, F.A.; Steinmetz, N.F.; et al. Treatment of Canine Oral Melanoma with Nanotechnology-Based Immunotherapy and Radiation. Mol. Pharm. 2018, 15, 3717-3722. [CrossRef]

251. Peranzoni, E.; Lemoine, J.; Vimeux, L.; Feuillet, V.; Barrin, S.; Kantari-Mimoun, C.; Bercovici, N.; Guérin, M.; Biton, J.; Ouakrim, H.; et al. Macrophages impede CD8 T cells from reaching tumor cells and limit the efficacy of anti-PD-1 treatment. Proc. Natl. Acad. Sci. USA 2018, 115, E4041-E4050. [CrossRef]

252. Prendergast, G.C.; Malachowski, W.; DuHadaway, J.B.; Muller, A.J. Discovery of IDO1 Inhibitors: From Bench to Bedside. Cancer Res. 2017, 77, 6795-6811. [CrossRef] [PubMed]

253. Zanganeh, S.; Hutter, G.; Spitler, R.; Lenkov, O.; Mahmoudi, M.; Shaw, A.; Pajarinen, J.S.; Nejadnik, H.; Goodman, S.; Moseley, M.; et al. Iron oxide nanoparticles inhibit tumour growth by inducing pro-inflammatory macrophage polarization in tumour tissues. Nat. Nanotechnol. 2016, 11, 986-994. [CrossRef] [PubMed]

254. Rodell, C.B.; Arlauckas, S.P.; Cuccarese, M.F.; Garris, C.S.; Li, R.; Ahmed, M.S.; Kohler, R.H.; Pittet, M.J.; Weissleder, R. TLR7/8agonist-loaded nanoparticles promote the polarization of tumour-associated macrophages to enhance cancer immunotherapy. Nat. Biomed. Eng. 2018, 2, 578-588. [CrossRef] [PubMed]

255. Chen, Q.; Wang, C.; Zhang, X.; Chen, G.; Hu, Q.; Li, H.; Wang, J.; Wen, D.; Zhang, Y.; Lu, Y.; et al. In situ sprayed bioresponsive immunotherapeutic gel for post-surgical cancer treatment. Nat. Nanotechnol. 2018, 14, 89-97. [CrossRef] 
256. Lu, K.; He, C.; Guo, N.; Chan, C.; Ni, K.; Weichselbaum, R.R.; Lin, W. Chlorin-Based Nanoscale Metal-Organic Framework Systemically Rejects Colorectal Cancers via Synergistic Photodynamic Therapy and Checkpoint Blockade Immunotherapy. J. Am. Chem. Soc. 2016, 138, 12502-12510. [CrossRef]

257. Vacchelli, E.; Aranda, F.; Eggermont, A.; Sautès-Fridman, C.; Tartour, E.; Kennedy, E.P.; Platten, M.; Zitvogel, L.; Kroemer, G.; Galluzzi, L. Trial watch: IDO inhibitors in cancer therapy. Oncoimmunology 2014, 3, e957994. [CrossRef]

258. Cheng, K.; Ding, Y.; Zhao, Y.; Ye, S.; Zhao, X.; Zhang, Y.; Ji, T.; Wu, H.; Wang, B.; Anderson, G.; et al. Sequentially Responsive Therapeutic Peptide Assembling Nanoparticles for Dual-Targeted Cancer Immunotherapy. Nano Lett. 2018, 18, 3250-3258. [CrossRef]

259. Tauriello, D.V.F.; Palomo-Ponce, S.; Stork, D.; Berenguer-Llergo, A.; Badia-Ramentol, J.; Iglesias, M.; Sevillano, M.; Ibiza, S.; Cañellas, A.; Hernando-Momblona, X.; et al. TGF $\beta$ drives immune evasion in genetically reconstituted colon cancer metastasis. Nature 2018, 554, 538-543. [CrossRef]

260. Rizvi, N.A.; Hellmann, M.D.; Snyder, A.; Kvistborg, P.; Makarov, V.; Havel, J.J.; Lee, W.; Yuan, J.; Wong, P.; Ho, T.S.; et al. Cancer immunology. Mutational landscape determines sensitivity to PD-1 blockade in non-small cell lung cancer. Science 2015, 348, 124-128. [CrossRef]

261. Zheng, Y.; Tang, L.; Mabardi, L.; Kumari, S.; Irvine, D.J. Enhancing Adoptive Cell Therapy of Cancer through Targeted Delivery of Small-Molecule Immunomodulators to Internalizing or Noninternalizing Receptors. ACS Nano 2017, 11, 3089-3100. [CrossRef]

262. Wang, Y.; Xu, Z.; Guo, S.; Zhang, L.; Sharma, A.; Robertson, G.P.; Huang, L. Intravenous Delivery of siRNA Targeting CD47 Effectively Inhibits Melanoma Tumor Growth and Lung Metastasis. Mol. Ther. 2013, 21, 1919-1929. [CrossRef] [PubMed]

263. Swartz, M.A.; Hirosue, S.; Hubbell, J.A. Engineering Approaches to Immunotherapy. Sci. Transl. Med. 2012, 4, 148rv9. [CrossRef]

264. Kuai, R.; Ochyl, L.J.; Bahjat, K.S.; Schwendeman, A.; Moon, J.J. Designer vaccine nanodiscs for personalized cancer immunotherapy. Nat. Mater. 2017, 16, 489-496. [CrossRef] [PubMed]

265. Thomas, S.N.; Vokali, E.; Lund, A.; Hubbell, J.; Swartz, M.A. Targeting the tumor-draining lymph node with adjuvanted nanoparticles reshapes the anti-tumor immune response. Biomaterials 2014, 35, 814-824. [CrossRef] [PubMed]

266. Nuhn, L.; Vanparijs, N.; De Beuckelaer, A.; Lybaert, L.; Verstraete, G.; Deswarte, K.; Lienenklaus, S.; Shukla, N.M.; Salyer, A.C.D.; Lambrecht, B.N.; et al. pH-degradable imidazoquinoline-ligated nanogels for lymph node-focused immune activation. Proc. Natl. Acad. Sci. USA 2016, 113, 8098-8103. [CrossRef] [PubMed]

267. Molino, N.M.; Neek, M.; Tucker, J.A.; Nelson, E.L.; Wang, S.-W. Display of DNA on Nanoparticles for Targeting Antigen Presenting Cells. ACS Biomater. Sci. Eng. 2017, 3, 496-501. [CrossRef] [PubMed]

268. Dewan, M.Z.; Galloway, A.E.; Kawashima, N.; Dewyngaert, J.K.; Babb, J.S.; Formenti, S.C.; Demaria, S. Fractionated but Not Single-Dose Radiotherapy Induces an Immune-Mediated Abscopal Effect when Combined with Anti-CTLA-4 Antibody. Clin. Cancer Res. 2009, 15, 5379-5388. [CrossRef] [PubMed]

269. Luo, M.; Wang, H.; Wang, Z.; Cai, H.; Lu, Z.; Li, Y.; Du, M.; Huang, G.; Wang, C.; Chen, X.; et al. A STING-activating nanovaccine for cancer immunotherapy. Nat. Nanotechnol. 2017, 12, 648-654. [CrossRef]

270. Hammink, R.; Mandal, S.; Eggermont, L.J.; Nooteboom, M.; Willems, P.H.G.M.; Tel, J.; Rowan, A.E.; Figdor, C.G.; Blank, K.G. Controlling T-Cell Activation with Synthetic Dendritic Cells Using the Multivalency Effect. ACS Omega 2017, 2, 937-945. [CrossRef]

271. Zhang, Q.; Wei, W.; Wang, P.; Zuo, L.; Li, F.; Xu, J.; Xi, X.; Gao, X.; Ma, G.; Xie, H.-Y. Biomimetic Magnetosomes as Versatile Artificial Antigen-Presenting Cells to Potentiate T-Cell-Based Anticancer Therapy. ACS Nano 2017, 11, 10724-10732. [CrossRef]

272. Stephan, M.; Moon, J.; Um, S.H.; Bershteyn, A.; Irvine, D.J. Therapeutic cell engineering with surface-conjugated synthetic nanoparticles. Nat. Med. 2010, 16, 1035-1041. [CrossRef] [PubMed]

273. Kranz, L.M.; Diken, M.; Haas, H.; Kreiter, S.; Loquai, C.; Reuter, K.C.; Meng, M.; Fritz, D.; Vascotto, F.; Hefesha, H.; et al. Systemic RNA delivery to dendritic cells exploits antiviral defence for cancer immunotherapy. Nature 2016, 534, 396-401. [CrossRef] [PubMed]

274. Colombo, M.; Raposo, G.; Théry, C. Biogenesis secretion and intercellular interactions of exosomes and other extracellular vesicles Annu. Rev. Cell Dev. Biol. 2014, 30, 255-289. [CrossRef] [PubMed]

275. Kahlert, C.; Kalluri, R. Exosomes in Tumor Microenvironment Influence Cancer Progression and Metastasis. J. Mol. Med. 2013, 91, 431-437. [CrossRef]

276. Liu, Q.; Rojas-Canales, D.M.; Divito, S.J.; Shufesky, W.J.; Stolz, D.B.; Erdos, G. Donor dendritic cell-derived exosomes promote allograft-targeting immune response. J. Clin. Investig. 2016, 126, 2805-2820. [CrossRef]

277. Wang, Y.; Zhang, D.; Wu, K.; Zhao, Q.; Nie, Y.; Fan, D. Long noncoding RNA MRUL promotes ABCB1 expression in multicellresistant gastric cancer cell sublines. Mol. Cell. Biol. 2014, 201434, 3182-3193. [CrossRef]

278. Wolf, P. The Nature and Significance of Platelet Products in Human Plasma. Br. J. Haematol. 1967, 13, 269-288. [CrossRef]

279. Mitchell, M. Complexity: A Guided Tour; Oxford University Press: Oxford, UK, 2009.

280. Mandelbrot, B.B. The Fractal Geometry of Nature; W. H. Freeman: New York, NY, USA, 1983.

281. Nottale, L. Scale Relativity and Fractal Space-Time-a New Approach to Unifying Relativity and Quantum Mechanics; Imperial College Press: London, UK, 2011.

282. Merches, I.; Agop, M. Differentiability and Fractality in Dynamics of Physical Systems; World Scientific: Singapore, 2016.

283. Wang, Y.; Cai, R.; Chen, C. The Nano-Bio Interactions of Nanomedicines: Understanding the Biochemical Driving Forces and Redox Reactions. Acc. Chem. Res. 2019, 52, 1507-1518. [CrossRef] 
284. Luo, N.; Weber, J.K.; Wang, S.; Luan, B.; Yue, H.; Xi, X.; Du, J.; Yang, Z.; Wei, W.; Zhou, R.; et al. PEGylated graphene oxide elicits strong immunological responses despite surface passivation. Nat. Commun. 2017, 8, 14537. [CrossRef]

285. Walkey, C.D.; Olsen, J.B.; Song, F.; Liu, R.; Guo, H.; Olsen, D.W.H.; Cohen, Y.; Emili, A.; Chan, W.C.W. Protein Corona Fingerprinting Predicts the Cellular Interaction of Gold and Silver Nanoparticles. ACS Nano 2014, 8, 2439-2455. [CrossRef]

286. Zhou, H.; Mu, Q.; Gao, N.; Liu, A.; Xing, Y.; Gao, S.; Zhang, Q.; Qu, G.; Chen, Y.; Liu, G.; et al. A Nano-Combinatorial Library Strategy for the Discovery of Nanotubes with Reduced Protein-Binding, Cytotoxicity, and Immune Response. Nano Lett. 2008, 8 , 859-865. [CrossRef] [PubMed]

287. Chaudhury, S.; Duncan, E.H.; Atre, T.; Storme, C.K.; Beck, K.; Kaba, S.A.; Lanar, D.E.; Bergmann-Leitner, E.S. Identification of Immune Signatures of Novel Adjuvant Formulations Using Machine Learning. Sci. Rep. 2018, 8, 1-11. [CrossRef] [PubMed]

288. Feng, R.; Yu, F.; Xu, J.; Hu, X. Knowledge gaps in immune response and immunotherapy involving nanomaterials: Databases and artificial intelligence for material design. Biomaterials 2020, 266, 120469. [CrossRef] [PubMed]

289. Xia, M.; Luo, D.; Dong, J.; Zheng, M.; Meng, G.; Wu, J.; Wei, J. Graphene oxide arms oncolytic measles virus for improved effectiveness of cancer therapy. J. Exp. Clin. Cancer Res. 2019, 38, 1-16. [CrossRef]

290. Lv, P.; Liu, X.; Chen, X.; Liu, C.; Zhang, Y.; Chu, C.; Wang, J.; Wang, X.; Chen, X.; Liu, G. Genetically Engineered Cell Membrane Nanovesicles for Oncolytic Adenovirus Delivery: A Versatile Platform for Cancer Virotherapy. Nano Lett. 2019, 19, $2993-3001$. [CrossRef]

291. Berkeley, R.A.; Steele, L.P.; Mulder, A.A.; Wollenberg, D.V.D.; Kottke, T.J.; Thompson, J.; Coffey, M.; Hoeben, R.C.; Vile, R.G.; Melcher, A.; et al. Antibody-Neutralized Reovirus Is Effective in Oncolytic Virotherapy. Cancer Immunol. Res. 2018, 6, 1161-1173. [CrossRef]

292. Draganov, D.D.; Santidrian, A.F.; Minev, I.; Nguyen, D.; Kilinc, M.O.; Petrov, I.; Vyalkova, A.; Lander, E.; Berman, M.; Minev, B.; et al. Delivery of oncolytic vaccinia virus by matched allogeneic stem cells overcomes critical innate and adaptive immune barriers. J. Transl. Med. 2019, 17, 100. [CrossRef]

293. Ferguson, M.S.; Lemoine, N.; Wang, Y. Systemic Delivery of Oncolytic Viruses: Hopes and Hurdles. Adv. Virol. 2012, 2012, 1-14. [CrossRef] 